\title{
BIPLIOGRAFIA
}

\section{Bibliografía de la novela colombiana}

\author{
PROLOGO
}

A falta de adecuados estudios bibliográficos y el difícil acceso - si no inaccesibilidad - del material mismo constituyen todavía los mayores obstáculos para el investigador en el campo de las letras hispanoamericanas. Para quien quiere estudiar la rica literatura colombiana, existe alguna que otra obra bibliográfica de índole general, aunque incompleta y de creciente inutilidad por ser ya de hace años; faltan, sin embargo, bibliografías especiales de épocas $y$ de géneros determinados. Sobre la novela colombiana, por ejemplo, género de que se discute -y aún en serio-- hasta la misma existencia, no hay ni bibliografía ni crítica que sirva para el estudio que ya merece. Esperamos, pues, que esta Bibliografía de la novela colombiana* sea sólo el primer paso en la documentación de la historia del género en Colombia. A otros les tocará completar el cuadro que aquí ofrecemos como guía y como promesa de una contribución máxima para el mejor aprecio y entendimiento de una faceta de la historia de las letras colombianas.

Por faltar aún los datos más elementales relativos a la mayoría de las obras y de los autores aquí inclúdos, decidimos proporcionar cuantos descubriéramos, prefiriendo arriesgar ser criticados por prolijos en informes marginales, que no guardarlos inéditos en nuestro archivo. El mismo deseo de juntar bajo un solo techo cuanto pudiéramos recoger sobre la novela colombiana nos animó a incorporar 
la traducción española, revisada y corregida, del ensayo por Gerald E. Wade, "Una introducción a la novela colombiana," publicada por la Revista de América (xv, 43-44, 1948, 67-81) de Bogotá. El ensayo salió primero en Hispania (xxx, 1947, 467-483), y antes de ser terminada esta Bibliografía, lo cual explica los errores y omisiones en el original, inevitables en aquel momento para cualquier estudio del género en Colombia. Revisado y corregido, pues, esperamos que sirva como ojeada rápida del desarrollo de la novela colombiana y como introducción a esta Bibliografía. A veces nos pareció bien documentarlo con nuevas citas y otros materiales sacados de ésta; pero por lo general hemos querido dejarlo más o menos en su forma original para no repetir lo dicho ya ni en el uno ni en la otra, prefiriendo más bien que se complementen en lo posible.

Por eso, conviene ahora llamar la atención a ciertas conclusiones que se nos permite sacar en claro a base de las notas críticas interpoladas con referencia a una proporción mayor de las obras, especialmente de las menos conocidas y poco o nada comentadas en ninguna parte. No fué nuestra intención ofrecer también una bibliografía extensa o completa de la crítica sobre la novela; en el caso de novelas como La vorágine, María, y algunas más, hemos citado de vez en cuando un estudio o reseña que a nuestro parecer no esté al alcance de todos o que fuese de los primeros hechos a raíz de la primera edición. De todas maneras los datos aquí reunidos se encuentran en pocos manuales sobre la literatura colombiana. Más exacto sería decir que son en gran parte inéditos.

Antes que nada fué nuestro deseo darle al investigador una idea del tipo y del contenido o argumento de cuantas novelas nos tocara leer o de cuantas adquiriéramos noticias a través de todas las fuentes a la mano. A veces nos ha servido el resumen de un crítico o prologuista; otras veces una que otra frase sacada del mismo texto, y en ocasiones nuestro propio sumario. Huelga decir, claro está; que muchas veces el mismo subtítulo sirve para clasificar una novela; en algunos casos, por habernos sido imposible consultar la obra misma o por habernos faltado otro medio de verificarlo, el subtítulo queda como el único indicio de clasificación.

Sin atrevernos a hacer — sólo a base de las susodichas notasunas generalizaciones categóricas con respecto a los tipos de novela 
más y mejor cultivados en Colombia, nos aventuramos a sugerir, sin embargo, que ciertas observaciones sobre este detalle bien podrían ser válidas. Parece indiscutible, por ejemplo, que la novela histórica y la novela de costumbres han sido los tipos predilectos del literato colombiano. Tanto la novela histórica como la de costumbres remonta a los mismos orígenes del género en el país, y las dos continúan siendo cultivadas hasta nuestros días con preferencia a casi todos los demás tipos. En el sentido más liberal y más justo de la palabra "historia," ¿no es "histórica" también la novela corta María Dolores de José Joaquín Ortiz, fundador del género novelesco en Colombia - si prescindimos de la obra de José Francisco Pereira que, según Ospina, fué publicada por' Nariño en 1815? Escrita en Anapoima en 1836 pero no publicada hasta 1841, Laverde Amaya clasifica la obra de Ortiz como "un cuadro de costumbres sencillamente narrado," añadiendo, sin embargo, que "la sinceridad con que está escrita ... demuestra que los hechos son verdaderos... que aquella historia de un matrimonio feliz bien puede ser..." la historia del propio autor. De todas maneras, apenas tres años después de publicada esta primera novela colombiana, apareció la primera novela histórica del cartaginense Juan José Nieto, Yngermina, o La hija de Calamar. Impresa en Kingston, Jamaica, en 1844, llevaba como subtítulo "Novela histórica, o Recuerdos de la Conquista, 1533-1537."

La Bibliografia nos permite ahora trazar el desarrollo histórico de estos dos tipos nacidos más o menos en la misma época como productos directos del romanticismo colombiano. El cuadro de costumbres dió vida a la novela de costumbres y la novela realista, contando ambas formas - el cuadro y la novela- con algunos de los autores y libros más célebres de la literatura nacional: Eugenio Díaz y su Manuela (1866), "novela de costumbres colombianas," Luis Segundo de Silvestre y su "novelita de costumbres americanas," Tránsito (1886), y otros menos conocidos hasta que se destacara el grupo antioqueño a fines del siglo, encabezado por el maestro Tomás Carrasquilla, cuyas obras Frutos de mi tierra (1896), El Padre Casafús (1914) y tantas otras, representan, en la opinión de muchos, "la culminación de la novela costumbrista en América." La novela histórica, que, en sus comienzos por lo menos, con frecuencia no pasaba de ser "cuadro histórico" (véanse, por ejemplo, los casos no- 
tables de los costumbristas José Caicedo Rojas y Medardo Rivas), fué cultivada con intensa devoción patriótica durante casi toda la segunda mitad del siglo pasado, alcanzando su máxima y mejor expresión quizá en el período 1860-1890. Es interesante notar también que la mujer colombiana se dedicara al género con especial fervor en aquel entonces, destacándose entre todas ellas que se llamaban Josefa Acevedo de Gómez, Evangelina Correa de Rincón Soler, Mercedes Gómez Victoria, y Priscila Herrera de Núñez, la fecundísima y talentosa escritora Soledad Acosta de Samper, que quiso hacer para Colombia lo que Pérez Galdós para España en los Episodios nacionales. El deseo de novelizar la historia y las costumbres colombianas dió como fruto un tipo de novela que a la autora le gustaba clasificar de "novela histórica y de costumbres nacionales." El único novelista histórico que le disputara a doña Soledad la primacía tanto en la ejecución como en la popularidad fué Felipe Pérez, el que "vulgarizó la historia en la novela..."

Aun en el caso de ejemplos sueltos de otros tipos de novela, prevalece como factor predominante el elemento terrígeno. María es un libro aislado, imposible de clasificar, única novela de un escritor reconocido por el mundo como el mejor de los novelistas románticos de América. Romántica es, y sin embargo, muy justa es la observación de Antonio Gómez Restrepo al afirmar que no obstante los elementos románticos, también "es una obra realista, una novela de costumbres, que está en armonía con la tendencia literaria del grupo de Isaacs...," es decir, de El mosaico (citada por OM, Hist., 236). El mismo elemento telúrico -ahora es la selva amazónica y los llanos del oriente- prevalece en otro caso extraordinario de la novela colombiana. La vorágine, poética, romántica y psicológica, es producto de una más aguda y más interesada compenetración del autor con su medio natural y social, y por eso se identificó desde luego con la novela de la violencia o de protesta social continental, siendo ella la primera del género en Colombia. Tuvo imitaciones, y crió familia, pero aun así la novela social no ha prosperado tanto en Colombia como en la mayoría de los demás países americanos. Sin embargo, es el tipo de novela que, juntamente con la novela histórica y la novela de costumbres, ha sido cultivado en Colombia con más conciencia y más constancia. La vorágine señaló el camino en 1924; había unos casos aislados hasta 1933, 
año en que maduró el fruto lineal de Toá. Desde entonces el colombiano ha intentado aprovecharse de la novela como medio de protestar por la explotación del campesino, del obrero, de los de abajo en general; el único autor del grupo que se distingue hasta hoy ha sido Gregorio Sánchez Gómez (1895-1942), que fué de los primeros en cultivar la novela social en el país. Es justicia añadir que Sánchez Gómez escribió otros tipos de novela también, y todos con éxito.

Respecto a las escasas muestras de otros tipos de novela cultivados en Colombia, que hemos podido encontrar, queda muy poco que comentar fuera de lo ya dicho en la Bibliografía. La novela psicológica - hasta hoy muy pobremente representada en la literatura hispanoamericana-- cuenta con pocos discípulos colombianos. Es interesante notar que entre los primeros fué Soledad Acosta de Samper en Laura (1870) -que la autora misma clasifica de "novela psicológica," y en La holandesa en América (1876)-cuyo subtítulo reza: "novela psicológica y de costumbres." Por cuanto hizo en pro de la mujer colombiana, era de esperarse que a doña Soledad le interesara sondear la psicología femenina y novelizar algunas de sus observaciones sobre ella. No fué, sin embargo, hasta la tercera década del siglo actual cuando la novela psicológica apareció como fruto legítimo del género moderno. Arango Ferrer llama a José Restrepo Jaramillo "el fundador de la novela psicológica" en Colombia, citando como prueba La novela de los tres y David, hijo de Palestina, publicadas entre 1925 y 1930, o en fecha aún más reciente. Wade señala a la novela Ayer, nada más del destacado dramaturgo Antonio Alvarez Lleras como ejemplo de lo que a él le parece ser el primer estudio psicológico escrito en el país. En vista de que no sabemos en qué año salió la primera edición de la obra, es posible que Alvarez Lleras le lleve la prioridad a Restrepo Jaramillo, o por lo menos que los dos empezaran a cultivar el género contemporáneamente. Conviene observar que aquél entró en el campo de las letras casi quince años antes que éste y que desde sus primeros escritos se ve la inclinación del joven dramaturgo hacia un análisis de la vida interior. En efecto, Ayer, nada más parece ser inspirado en el mismo problema fundamental de su obra dramática Como los muertos. Indiscutiblemente posterior a éstos, Félix Henao Toro pide por sí mismo en el prólogo a su novela Eugeni la pelotari (1935), el título de innovador "Hasta donde mis noticias alcanzan ésta es la 
primera novela psicoanalítica que se escribe en español." $\mathrm{El}$ determinar a quién le toca la prioridad en el asunto, dentro de un período tan estrecho de tiempo, es lo de menos; lo que sí nos llama la atención es la importancia que se da al hecho mismo, prueba, a nuestro parecer, de que hasta 1925 ningún novelista colombiano se pusiera a escribir, con la clara conciencia de su tarea, una novela psicológica a la moderna. Hasta hoy, como se verá, la cosecha ha sido nula; quizás los que con más genio abordaron lo psicológico en algunas de sus obras, si no en todas, eran Daniel Samper Ortega y Gregorio Sánchez Gómez.

De los restantes tipos de novela, a veces no se da sino un solo ejemplo en Colombia, sin hablar de novelistas de tal o cual tipo ni de épocas en que predomine uno que otro. Algunos casos aislados de novela biográfica y de novela epistolar; un caso de novela policial, otro de novela infantil, nada de novela imaginativa de grandes aventuras. La novela moderna colombiana sigue siendo primordialmente terrígena, distanciada de la del siglo pasado por un mejor dominio de la técnica y por una creciente preocupación social.

Una ojeada rápida a esta Bibliografía debe de poner en claro esta observación final: en los últimos años la ficción, tanto el cuento como la novela, empieza a ocupar un lugar más respetado en el mundo de las letras colombianas. Al afirmar esto no queremos, por supuesto, negar ni las obras cumbres del pasado ni cosechas $\tan$ buenas y generosas como la del grtupo antioqueño.

Esperamos que otros datos en ésta incluídos sean útiles para distintos grupos de investigadores. Para el filólogo no dejamos de incorporar ninguna referencia a glosario, riqueza léxica, localismos, dialecto negro, giros peculiares; le interesará saber, por ejemplo, que de Minas, mulas y mùjeres de Bernardo Toro podría hacer un "verdadero escrutinio de vocabulario popular ( $\mathrm{y}$ aún del plebeyo) ...," ya que en ella abundan "los giros peculiares, los modismos de casa, campo y calle, las expresiones de vívido realismo..." El investigador en el campo de la literatura comparada ha de complacerse en encontrar unos cuantos datos relativos a la influencia de ciertos novelistas europeos en Colombia. Del prólogo a su Episodios novelescos de la historia patria (1887), no pudimos menos de sacar 
esta preciosa nota que nos ofrece doña Soledad Acosta de Samper: “... en todas las novelas históricas que hemos escrito procuramos tomar por norma al criador de ellas, a Walter Scott..." Más tarde, en 1905, la misma doña Soledad se identificó con el creciente círculo de novelistas galdosianos, confesando que al formular el plan de la serie de novelas intitulada "Los españoles en América," procuró "imitar... al insigne Pérez Galdós." El joven Diego Rafael de Guzmán, ferviente discípulo de Cervantes, calificó de "novelas ejemplares" a sus primeros ensayos novelescos, componiendo más tarde, 1876-1878, dos curiosas novelitas tituladas Resignación y $L a$ Cruz de mayo que merecen estudiarse como textos de lengua, "como interesantes adaptaciones del giro cervantino a asuntos nacionales..." Y en Alonso Quijano el bueno (1930), Julián Motta Salas emprendió la tarea delicada de hacer salir otra vez al hidalgo Don Quijote, no "con manías de imitación," sino como' "himno de cariño y de veneración."

Las fuentes, sin embargo, no eran siempre exclusivamente europeas; nadie menos que Felipe Pérez, príncipe de los novelistas históricos, en que bien se nota la influencia de Dumas, acudió, según Cortázar, a "la crítica juiciosa del célebre Prescott" para orientarse en la creación de sus "novelas indianas" de tema incaico.

Finalmente, el lector sabrá apreciar datos como el que nos proporciona Ospina con referencia al cartaginense José Francisco Pereira, autor de La lanza del célebre pijao don Baltasar, desconocida para los demás, que publicara Nariño en 1815, y que parece ser la primera novela colombiana. $Y$ ha de apreciar también noticias sobre las obras premiadas, sobre las traducidas - no hacemos referencia a obras traducidas sólo en parte, sobre los seudónimos recogidos - aunque no siempre usados en el caso de las novelas aquí citadas, y sobre los proyectos en prensa y a veces sólo en mente.

Sabemos perfectamente bien que no pocas de las obras aquí recogidas podrían ser mejor clasificadas de cuento, de cuadro histórico o leyenda, o de cuadro de costumbres. En el caso de algunas obras citadas como novelas por los críticos, que nos fué permitido examinar, pudimos verificar que eran más bien "ensayos," "cuentos cortos," "impresiones de viaje" y así por el estilo, que en ningún 
sentido de la palabra podrían entrar en la categoría de "novela." A veces decidimos incluir una obra no examinada -y de que no pudimos comprobar nada- sólo a base del título, del número de páginas, y de lo poco que pudimos verificar con respecto a los géneros literarios preferentemente cultivados por el autor. Faltándonos estos mínimos informes, hemos seguido la política de excluir todos los demás. En algún que otro caso mencionamos, en una nota, las obras que a nuestro parecer podrían ser novelas. Véase, por ejemplo, la nota final con respecto a Fernando González. En el caso de las obras clasificadas por el mismo autor - y a veces por los críticos - como "novela," o "novelita," o "novela corta," o "nivola," o "novelín," cuya clasificación, a veces, nos pareció algo forzada, hemos preferido respetar la categoría a que fueron asignadas. Hemos sido más que arbitrarios, quizá, en haber incluído todos los títulos publicados en la conocida serie "Ia novela semanal," fundada por Luis Enrique Osorio en 1923 ; no cabe duda de que la mayoría de esas novelas cortas y "novelitas" no son más que cuentos. Preferimos, sin embargo, no intentar escoger entre cuento y novela corta, lo cual hubiera resultado también altamente arbitrario. Eduardo Castillo nos defiende bien la posición adoptada al hacer este comentario con respecto a La ráfaga, Lili y La selva oscura de Emilio Cuervo Márquez: “... no son novelas propiamente dichas. Son ... lo que los franceses llaman nouvelle, y los españoles novelín." E1 criterio de selección fué resuelto por la determinación de "pecar por lo de más que por lo de menos."

Hemos preferido incluir sólo los nombres de novelistas que podrían ser acompañados de su obra u obras; dánse muchos casos en que los bibliógrafos y biógrafos citan a escritores como novelistas $\sin$ hacer referencia a ninguna obra, $y$ sin habernos sido posible descubrir tampoco ninguna que fuera de su pluma. Una de las pocas excepciones a esta regla es el caso de la conocida escritora Silveria Espinosa de Rendón. Ortega dice que "cultivó la novela ..."; no hemos podido confirmar el dato, ni aun con obra suya que caiga en el terreno nebuloso de cuento-novela corta. Nos pareció bien, sin embargo, recoger esta afirmación de Ortega, con la esperanza de que otros pudieran comprobarla. 
Los nombres de los autores, inclusive los seudónimos, aparecen en orden alfabético, seguidos de cuantos seudónimos empleasen, de lugar de nacimiento, y de fechas de vida y muerte. Las obras están catalogadas en orden cronológico de su primera publicación - sea en forma de libro, sea en publicación periódica--, las ediciones posteriores sucediéndose cronológicamente tras la primera. De cada obra se dan: clasificación y subtítulo, si los hay; lugar y fecha de publicación; casa editorial, y número de páginas. Infórmase también si contiene prólogo, prefacio, introducción, $\mathrm{u}$ otro vehículo de palabra preliminàr, y si trae ilustraciones de cualquier clase, dibujos, foto, mapa, etc. $\mathrm{Y}$ al final cítanse las bibliotecas en donde se la puede encontrar. Las novelas citadas como "en preparación," "para publicarse," o ya publicadas, y de las cuales nos falta todo dato bibliográfico, aparecen tras el libro en que primero fueran anunciadas. Al faltar datos bibliográficos para una obra citada como novela, siempre indícase la fuente de tal informe. Los demás datos relativos a una sola obra vienen en nota aparte al final; datos sobre el novelista y sus libros en conjunto siguen al último título. Como regla general cada obra aparece como entrada aparte, aun en el caso de ser publicada sólo en forma antológica; hemos hecho alguna que otra. excepción en el caso de un número de novelas cortas publicadas juntas en un solo volumen. Tal, por ejemplo, el caso de Josefa Acevedo de Gómez o de Enrique Alvarez Bonilla. Las abreviaturas responden a dos principales divisiones: 1. Futentes bibliográficas, y 2 . Bibliotecas, en donde quedan depositadas las obras consultadas. Las otras son obvias.

Si nuestra labor merece una aprobación general, queremos que la compartan con nosotros los muchos amigos y colegas que tan generosamente nos ofrecieron su ayuda y estímulo. A los buenos colaboradores colombianos de la Academia Colombiana de Historia, de la Biblioteca Nacional en Bogotá, de la Biblioteca Pública de Cartagena, y de la Biblioteca Santander de Medellín, van nuestras cordiales y profundas gracias que recogerán, en nombre de todos, los finos amigos Gustavo Otero Muñoz, ex presidente de la Academia Colombiana de Historia e historiador ejemplar de la literatura nacional, y Luis Augusto Cuervo, director del Boletín de Historia y Antigüedades y dueño de la mejor colección, particular o pública, de la novela colombiana. Y que acepte el viejo colega Sturgis E. Leavitt, 
en nombre de sus colaboradores, nuestro agradecimiento por datos sobre obras publicadas en ciertas revistas literarias de Colombia, sacados de una bibliografía del contenido de un número considerable de las más importantes de la América española, que, y dicho sea con pena, queda inédita todavía, y aun inaccesible para muchos que quieren contribuir a una mayor difusión y mejor apreciación de la literatura hispanoamericana.

\author{
JoHN E. ENGLEKIRK, \\ Tulane University. \\ Gerald E. Wade, \\ University of Tennessee.
}

* Tanto las investigaciones llevadas a cabo por John E. Englekirk en bibliotecas públicas y particulares de Colombia durante el verano de 1947, como la ayuda de una secretaria asistente, se deben, en parte, a fondos de la Carnegie Research Grant administrados por Tulane University. 


\section{ABREVIATURAS}

\section{Fuentes Bibliográficas}

$\mathrm{AF}$

BP

BPCC

Cat. Libr.

Colombiana

Cortázar

LA

Ladrón

Latcham

Latorre

L-GP
Arango Ferrer, Javier, La literatura de Colomoia. Buenos Aires, "Coni", 1940, 158.

Bayona Posada, Nicolás, Panorama de la literatura colombiana. Bogotá, Eds. Samper Ortega, 1942, 145.

Biblioteca Popular de Cultura Colombiana.

Catálogo de la Libreria Colombiana (Camacho Roldán \& Cía.), Calle 12, No 7-50, Bogotá.

Cortázar, Roberto, La novela en Colombia. Bogotá, Imp. Eléctrica, 1908, VIII + $112+$ VI.

Laverde Amaya, Isidro, Bibliografía colombiana. Tomo I. Bogotá, Imp. Medardo Rivas, 1895, 296.

Ladrón de Guevara, Padre Pablo, Novelistas malos y buenos. 1 ed., Bogotá, 1910; - 4 ed., Bilbao, El Mensajero del Corazón de Jesús, 1933, 676.

Latcham, Ricardo A., "Perspectivas de la novela colombiana actual", Revista de la Universidad del Cauca, 9, junio, 1946, 1-31.

Latorre, Mariano, "Primera glosa sobre la novela en la América del Sur", Atenea (Chile), xxxiv (1936), 154-167.

Leavitt, Sturgis E. y García-Prada, Carlos, $A$ Tentative Bibliography of Colombian Literature. Cambridge, Harvard University Press, 1934, 80. 
OM, Boletín Otero Muñoz, Gustavo, "Soledad Acosta de Samper", Boletín de historia y antigüedades (Bogotá), Xxiv (1937), 257-283.

OM, Hist. Otero Muñoz, Gustavo, Historia de la literatura colombiana, 5 ed. Bogotá, Librería Voluntad, 1945, 323.

Ortega - Ortega, T., José J., Historia de la literatura colombiana. 2 ed. Bogotá, Cromos, 1935, xL-1214.

Ospina Ospina, Joaquín, Diccionario biográfico y bibliográfico de Colombia. Tomo I. Bogotá, Cromos, 1927, 828. De A a F; Tomo II, Bogotá, Edit. Aguila, 1937, 836. De G a M ; Tomo irt, 1937, 1026. De M a Z.

SSO Selección Samper Ortega de literatura colombiana. Bogotá, Minerva, 1937. Cien volúmenes.

Wade Wade, Gerald E., "An Introduction to the Colombian Novel", Hispania, xxx (1947), 467-483.

\section{Bibliotecas}

$\mathrm{BN}$

Biblioteca Nacional (Bogotá).

BPB

Biblioteca Pública de Barranquilla.

$\mathrm{BPC}$

Biblioteca Pública de Cartagena.

BSM

Biblioteca Santander de Medellín.

C

University of California Library (Berkeley).

$\mathrm{CH}$

University of Chicago Library.

D

Duke University Library (Durham).

I1

LAC

University of Illinois Library (Champaign-Urbana).

LC

Biblioteca particular de Luis Augusto Cuervo.

$\mathrm{NC}$

Library of Congress (Washington, D. C.).

$\mathrm{T}$

University of North Carolina Library (Chapel Hill).

$\mathrm{Te}$

Tulane University Library (New Orleans).

$\mathrm{Y}$

University of Texas Library (Austin).

Yale University Library (New Haven, Connecticut). 


\section{BIBLIOGRAFIA}

Acevedo de Gómez, Josefa (Bogotá, 1803-1861)

Cuadros de la vida privada de algunos granadinos. Bogotá, "El mosaico," 1861, II-196. BN.

Contiene las siguientes novelas cortas históricas: El triunfo de la generosidad sobre el fanatismo político; El soldado; Valerio o el calavera; Angelina; La caridad cristiana; El pobre Branlio; La vida de un bombre; $\mathrm{y}$ Mis recuerdos de Tibacuy. Esta última $\mathrm{y}$ "El amor conyugal" se incluyen en la SSO: $11,23-33$.

Véase: Ladrón, 18-19.

Acks, Modesto (Véase: Rendón, Francisco de Paula)

Acosta de Samper, Soledad (seud. Aldebarán; Andina; Bertilda; Olga;

Renato) (Bogotá, 1833-1913)

Dolores (Cuadros de la vida de una mujer), en El mensajero (Bogotá), 1867. Firmada: Aldebarán; -, en Novelas y cuadros de la vida suramericana (Gante, Eug. Vanderhaeghen, 1869, vI-438. Pról. José María Samper), 1-72. LC Y.

Trad. Dolores: The story of a leper. New York.

Véase: OM, Boletín, 265, 279. No se pudo confirmar el dato.

"La acción ... versa sobre los amores de una muchacha de aldea, romántica y artista, hacia cierto joven bogotano, a quien conoce en unas fiestas de su pueblo. Mas la fatalidad... viene a interponerse entre los dos enamorados: el terrible mal de Lázaro, heredado de su padre por Dolares, se apodera del grácil cuerpo de ésta, y hace imposible la unión de los jóvenes. La autora nos describe con grave sencillez los estragos físicos 
y morales de la enfermedad, y el proceso del drama interior que desgarra el corazón de la protagonista... El mayor mérito consiste seguramente en la gran verdad de los caracteres y de las descripciones." OM, Boletín, 265 .

Teresa la limeña (Páginas de la vida de una peruana), en La prensa (Bogotá), 1868; - , en Novelas y cuadros de la vida sur-americana (1869), 73-233.

"... el resultado de la experiencia de sus observaciones en la sociedad del Rímac." OM, Boletin, 265.

El corazón de la mujer (Ensayo psicológico, en Novelas y cuadros de la vida sur-americana (1869), 237-348; -, Curazao, A. Bethencourt e hijos, $1887,124$.

José Antonio Galán (Episodios de la guerra de los comuneros), en El bien puiblico (Bogotá), 1-7, julio, 1870; -, en Episodios novelescos de la historia patria. La insurrección de los comuneros, Bogotá, "La luz," 1887, vir-191. Primera parte: José Antonio Galán. Segunda parte: Juan Francisco Berbeo. Pról. La autora. "La antigua provincia del Socorro," por José María Samper, 3-9. "Introducción": La autora. BN C Y.

"... en todas las novelas históricas que hemos escrito procuramos tomar por norma al creador de ellas, a Walter Scott... los hechos que presenta la historia como sucedidos verdaderamente no los alteraremos jamás; en lo que no la seguiremos siempre es en el carácter frecuentemente equivocado de los personajes; y en los móviles que tuvieron ... buscaremos en todo caso lo verosímil y probable." Pról.

"... episodio novelesco sobre la insurrección de los comuneros, ampliado y complementado... con una segunda parte sobre 'Juan Francisco Berbeo." OM, Boletin, 266.

Laura (Novela psicológica), en El bien público, (Bogotá), 34-40, noviembre-diciembre, 1870.

"Novela psicológica, de índole sentimental y docente, que se basa en un caso de ... bigamia, terminada en tierno idilio de ultratumba entre el esposo culpable y la digna compañera ofendida, quien sólo perdona y vuelve a amar en el instante supremo de la muerte." OM, Boletín, $265-266$.

Constancia, en El bien príblico (Bogotá), 76-90, abril-junio, 1871. 
"Hechicera figura de mujer apasionada y superior, cuya historia vemos deslizarse entre rosas y espinas." OM, Boletin, 266.

Anales de un paseo, en El tradicionista (Bogotá), septiembre-octubre, 1872; - en La mujer (Bogotá), junio de 1879 a septiembre de 1880 . cionista.

"Novelas y cuadros de costumbres." Quedó inconclusa en El tradi-1

La bolandesa en América (Novela psicológica y de costumbres), en La ley (Bogotá), 2-27, marzo-julio, 1876; Una bolandesa en América (Novela), Curazao, A. Bethencourt e hijos, 1888, v-390. Pról. Los editores. BPC C IAC.

"... aparecen dibujadas con mano hábil algunas costumbres de las gentes rústicas y también de las cultas de Colombia, acompañadas de largos e interesantes episodios de la historia moderna de csta república, como la insurrección de Melo, entretejidos con reflexiones y sentencias bien meditadas, al favor de una trama novelesca que hunde sus raices en la naturaleza humana, y de acuerdo con el estado social y político del país en la época que abraza la parte narrativa de la fábula desarrollada "por la autora." OM, Boletín, 267.

Gil Bayle (España en 1390. Leyenda histórica), en La ley, (Bogotá), 26-30, julio, 1876; - en El domingo (Bogotá), octubre-diciembre, 1898; -, Bogotá, "La luz," 1898, 732. LAC.

También contiene Los bidalgos de Zamora.

Primera novela de la serie "Los españoles en España." Véase: "Dos palabras al lector," en El domingo (Bogotá), r, 1, 2 de octubre, 1898, 59-61, en que la autora explica el plan general de la serie de novelas históricas que se propone emprender:

"Nos hemos propuesto, pues, emprender ... una serie de novelas históricas que pintan, bajo una forma familiar, la historia de nuestra patria, desde su conquista hasta nuestros días ... presentando la historia vestida de gala y bajo el aspecto más interesante, pero sin quitarle su semejanza ... procurando únicamente idear sencillas tramas... Servirán de introducción a esta serie... dos en las cuales pintaremos a Los españoles en España; a saber, en 'Gil Bayle,' al español del feudalismo puro, y en 'Los hidalgos de Zamora,' al español del Renacimiento.

Las épocas del Descubrimiento, la Conquista y la Colonización irán descritas en varias novelas largas y de costumbres de aquellos tiempos; 
la Independencia y lo relativo a la actualidad formará otra serie en la cual procuraremos pintar la sociedad colombiana por todas sus faces. Cada novela larga formará un volumen aparte, pero las relaciones histórico-novelescas cortas se reunirán en tomos que contengan seis o más cuadros aislados. La serie entera compondría la historia dramático-novelesca de una parte de Hispano-América, desde la llegada de los españoles al Nuevo Mundo hasta nuestros días."

"...la más ambiciosa empresa novelística que hayamos tenido." OM, Boletin, 266.

Doña Jerónima (Novela de costumbres neo-granadinas), en $L a m u$ jer (Bogotá), septiembre de 1878 a enero de 1879. Firmada: "Olga."

Los hidalgos de Zamora (Novela histórica y de costumbres del siglo xvi), en El deber (Bogotá), 1-23, octubre-diciembre, 1878. Fechada en Bogotá, julio de 1873; - Bogotá, "La luz," 1898, 732. Véase: Gil Bayle; -, (Novela histórica. Costumbres en España en el siglo xvI), en El domingo (Bogotá), abril-septiembre, 1899.

Las dos reinas de Chipre (Siglo xv. Cuadros de la historia chipriota), en La mujer (Bogotá), noviembre de 1878 a abril de 1879.

Los descubridores. Alonso de Ojeda (Cuadros históricos y novelescos. Siglo xv), en La mujer (Bogotá), enero-diciembre, 1879; Un bidalgo conquistador (Episodios histórico-novelescos), Bogotá, "La luz," 1907, 298. LAC Y.

Primera novela de la serie "Los españoles en América." Fechada en noviembre de 1875 .

El talismán de Enrique (Novela), en La mujer (Bogotá), febrerojunio, 1879. Firmada: "Aldebarán."

Novela de costumbres, de hechos verídicos.

La juventud de Andrés (Novela histórica y de costumbres nacionales. Fin del siglo xvIII), en La mujer (Bogotá), diciembre de 1879 a agosto de 1880 .

Historia de dos familias (Novela de costumbres nacionales), en $L a$ mujer (Bogotá), julio-noviembre, 1880. Firmada: "Olga."

Una flamenca del siglo XVI, en La mujer (Bogotá), agosto-octubre, 1880 . 
La familia de tío Andrés (Epoca de la Independencia. Segunda parte de La juventud de Andrés. Novela histórica y de costumbres nacionales), en La mujer (Bogotá), noviembre de 1880 a mayo de 1881.

Una mujer modelo, en La luz (Bogotá), octubre, 1881.

Fragmento de una novela de costumbres.

Una familia patriota (Cuadros de la épocia de la Independencia), en La familia (Bogotá), 1884-1885.

Continuación de La familia de tío Andrés.

Los piratas en Cartagena (Crónicas histórico-novelescas) Bogotá, "La luz," 1886, XIII-275. Carta al señor doctor Rafael Núñez. Contestación del señor Presidente de Colombia. Ch Y.

“... el más interesante de los que escribió doña Soledad dentro del género, por su estilo preciso y claro, y por la habilidad en la distribución de los resortes novelescos, en que mezcla la parte histórica con la romántica..." OM, Boletin, 267.

Véase: Ladrón, 23-24.

Quien busca balla (Novela de costumbres nacionales).

Fechada el 20 de julio de 1899. Fué publicada como folletín de periódico bogotano en el año de 1903. OM, Boletín, 281.

Aventuras de un español entre los indios de las Antillas, en Lecturas para el hogar (Bogotá), junio de 1905 a abril de 1906.

Segunda novela de la serie "Los españoles en América." Dice la autora: "Hemos procurado en esto imitar ... al insigne Pérez Galdós."

Un cbistoso de aldea (Cuadros de costumbres populares), en Lecturas para el bogar (Bogotá), 1905.

Justicia cumplida la de Dios venida (Novela de costumbres nacionales), en Lecturas para el hogar (Bogotá), septiembre de 1905 a febrero de 1906.

El esclavo de Juan Fernández.

Citada por LA como novela escrita en francés y publicada en un periódico de París titulado El eco literario. 
Aventuras de Antonio Pérez en la Corte de Navarra.

"Sólo en parte se ha publicado esta novela ..." Ladrón, 24-25.

LA cita las siguientes como novelas inéditas: Vasco Núñez de Balboa; El tirano Aguirre; Los tres asesinos de Eduardo; Una reina del siglo VI; Buen corazón quebranta mala fortuna.

OM, Boletin, 267, también cita las dos primeras como "inéditas." De las otras no se tiene noticia alguna.

Agudelo, Miguel (Medellín)

Momentos de vida. Medellín, Imp. Editorial, 1911, 63. BSM.

Aguilar, Federico Cornelio (Bogotá, 1834-1887)

Matilde, o escenas de la revolución de Colombia de 1876, en La estrella de Chile, 1877-1878; -, en El pasatiempo (Bogotá), 1877-1878.

Ignacio Borda la reprodujo en su periódico El pasatiem po, "suprimiendo no pocos párrafos de alusiones políticas incandescentes." LA, 17.

Alas, Claudio de (Véase: Escobair Uribe, Jorge)

Albarracín (C), Jacinto

Almíbar. Bogotá, "La luz," s. f. [1901], vm-319. Pról. Alejandro Vega. LAC.

En prep. Don Cosme (Novela).

Castidad... ? (Novela). Bogotá, "El ciclón," 1903, 168. BN.

Aldebarán (Véase: Acosta de Samper, Soledad)

Alvarez, Secundino M. (Tolima, 1830-1877)

Las guerras de Itamol (Novela histórica).

Suspendióse la publicación. Lugar y fecha desconocidos. "Dejó inéditos algunos trabajos, una novela..." LA, 23.

Alvarez Bonilla, Enrique ('Tunja, 1848-1913)

Escenas de bogar (Novela). Bogotá, "La luz," 1892, 231. BN. 
Contiene las siguientes, novelas cortas: Elvira, 3-29; Apariencias, $30-$ 43; Bien por mal, 44-65; Amistades desiguales, 66-83; Un manuscrito, 84-102; Un albacea, 103-128; Alma-ángel, 129-151; El dios del siglo, 152-232.

Véase: LA, 25; Ladrón, 37.

Alvarez Garzón, Juan

Los Clavijos. Bogotá, Cromos, 1943, 278. BN NC.

"Novela histórica que relata interesantísimo y sonado episodio ocurrido en el sur de Colombia, en tiempos de la Independencia." Cat. Libr. Colombiana, 1945.

Homófono de Freixas (Novela).

Anunciada en Los Clavijos.

Atvarez Lleras, Antonio (Bogotá, 1892- )

Aycr, nada más (Novela). 3 ed. París, "Le livre libre," 1930 , 440. BN.

Véase: Wade, 480.

Alvear Restrepo, José (Antioquia)

El bombre de la granja. Medellín, Tip. Industrial, 1945, 188. Pról. balmore Alvarez G. LC.

La primera parte de una novela que su autor pensaba continuar. Una bella evocación de la vida rural antioqueña, mas afeada por la intrusión de varias cosas que poco tienen que ver con la trama principal.

AmÉzquita, Cándido

La mujer infiel. (Apuntes de la vida íntima en forma de novela histórica). Bogotá, "La luz," 1887, Ix-107. Pról. El autor. LAC.

Fechada en Bucaramanga el 31 de diciembre de 1886.

"... no una novela, sino los apuntamientos para una obra; apuntamientos de la existencia pública y privada del que nos ocupa ... Para 
la mejor coordinación de la historia, me veo obligado a intercalar los sucesos de las revoluciones hasta 1885." Pról.

Véase: Ladrón, 37.

Andina (Véase: Acosta de Samper, Soledad)

Andréts, Fernando de

Tula del Real, en La novela semanal (Bogotá), I, 19, 31 de mayo, 1923, 193-205. BN Y.

Angel Gaitán, José María (Bogotá, 1819-1851)

El doctor Temis (Novela original). Bogotá, Imp. Imparcial, 1851, x-309. "Nota biográfica": José María Maldonado Castro. LAC. 一, Bogotá, 1857; -, París-Bogotá, Garnier-Camacho, Roldán y Tamayo, 1897, 2 v. Xxvin-281-302. Pról. Isidoro Laverde Amaya. "Noticia bibliográfica": J. M. M. C. (de la 1 ed.). Bibl. de los novelistas. LAC LC Y.

"... una novela de costumbres bogotanas, y el principal asunto... está tomado de la célebre compañía de ladrones que encabezó... el doctor Russi, quien duró mucho tiempo burlándose de la injusticia... Si como creaciones de la fantasía son superiores Manuela y María... no menos cierto que $E l$ doctor Temis puede parangonarse con las anteriores novelas por lo trágico de su argumento y por el desarrollo de la trama, interesante y bien manejada." LA, 34-36.

"Su amigo de intimidad el doctor José María Maldonado Castro escribió la introducción para la única obra que salió de la pluma de Gaitán y que empezó a publicarse por entregas y sin su firma. Pocos meses después de la muerte de éste, fué cuando dicho señor Maldonado dió a la luz pública la edición completa con el nombre del autor; ... en ese tiempo la publicación de una novela de las proporciones de la de Angel, con trama complicada y situaciones dramáticas de efecto, a estilo de las obras francesas, tenía que ser para la tranquilidad social bogotana un verdadero acontecimiento." Ospina, 102.

Véase: Cortázar, 2-7; Ladrón, 41.

\section{Angulo, Enriqueta}

Valor moral, en La novela semanal, 1, 26, 19 de julio, 1923, 273-282. 
ANJelo (Véase: Arbeláez, Juan Clímaco)

\section{ANónimo}

Maria, $i$ las coincidencias (Novela original. Escrita por un santafereño). Bogotá, "El núcleo liberal," 1858, 25. BN.

Historia de una noche, escrita por un colaborador de La patria (Bogotá).

Citada por Cortázar, "Apéndice."

Apemanto (Véase: Pizarro, Alejandro)

Arango, Antonio J.

Oro y miseria. Manizales, Edit. El Libro, 1942, 143. BN.

Anuncia haber publicado también las siguientes obras que parecen ser novelas: El dilema de un vagabundo; Bajo cero; y Quindio.

Arango Vélez, Dionisio (Cartagena, 1895- )

El inocente (Novela). Bogotá, Minerva, 1929, 188. LC.

Reza el subtítulo: "Psicoanálisis de la infancia neurótica y de otros productos sociales del medio ambiente bogotano, con un prefacio del autor sobre educación sentimental de los menores." Termina la novela con una traducción de "If ..." de Kipling, 187-188, "A manera de apéndice."

Para publicarse: Los notables (Novela).

Memorias de un tal Pastrano (Mojiganga baladí). Bogotá, Cromos, 1931, 280. Pról. El autor. LC.

". . . novela de buen humor, picaresca ... Otro de nuestros propósitos ... ha sido el de remozar un algo nuestro idioma de todos los días ..." Pról.

Arango Villegas, Rafael (Caldas)

Asistencia y camas (Novela costumbrista). Manizales, Arturo Zapata, 1934. 
"Estas obras son de importancia para el estudio del lenguaje regional." Ortega, 1025 .

Arbeláez, Juan Climaco (seud. Anjelo) (Antioquia, 1844- )

Adelaida Helver. Bogotá, Nicolás Pontón, 1868, 34.

Ardila Casamtjana, Jaime (Bucaramanga, 1919- )

Babel. La Plata, Calomino, 1943, 191.

Arenas, Jesús (Antioquia)

Ynés (Novela basada en acontecimientos de la revolución civil colombiana de 1899). 1 ed. Manizales, "El renacimiento," 1908, 126. LAC.

Luchas sociales (Novela), 1 ed. Manizales, Tip. Caldas, 1920, 348.

Véase: Ladrón, 44.

Artas Argáez, Daniel (Bogotá 1869- )

Un pescador de perlas (Novela de costumbres bogotanas), Bogotá, Minerva, 1925, 292. Ils. LC.

"... se revela un poeta, un escritor de costumbres y un estilista ameno... E1 libro tiene un doble fondo, de moralidad y de progreso social. Su quemante anatema ... contra el tipo tan común de los maridos que se casan para dilapidar criminalmente el capital de las mujeres . . . La descripción de la peste de la gripa en Bogotá, en 1918, es un excelente capítulo para la historia del espantoso flagelo en Colombia y para mostrar el espíritu cristiano y altruista de nuestra hermosa capital." José M. Saavedra Galindo, Cromos (Bogotá), XxI, 498, 20 de marzo, 1926.

\section{Arias Bernal, José Domingo}

Wilbelm (Obra epistolar. Contestación a la novela de Goethe, intitulada Werther). Buenos Aires, Imp. López, 1943, 224. Pról. El autor. LC NC T.

"... no es novela, ya que carece de trama. Y si en todo libro hay algo de autobiografía, Wilhelm quiso exteriorizar afecciones intimas." Puede ser clasificada como novela epistolar. 
Arrias Suárez, Eduardo (seud. Constantino Pla) (Armenia 1896- )

Ortigas de pasión (Tres novelas breves). Bogotá, Edit. El Escolar, $1939,246$.

Contiene: Sol de los venados, El niño-Dios y La solterona. "3 bellas novelas cortas de temas vernáculos." Cat. Libr. Colombiana, 1945.

Envejecer (Novela breve), en SSO: 17, 133-169.

Bajo la luna negra Novela inédita, escrita en la Guayana holandesa.

Amas Trujullo, Bernardo (Manizales 1905-1939)

Risaralda (Película de negredumbre y de vaquería, filmada en dos rollos y en lengua castellana). Manizales, Arturo Zapata, 1935, 266. LC NC; - 2 ed. Bogotá-Medellín, Libr. Siglo XX, 1942, xxrv-243. Pról. Silvio Villegas.

"... la titánica epopeya de la colonización del valle de Risaralda, realizada hace cuarenta años." Pról.

"... una de las mejores novelas de la última producción. Arias Trujillo estuvo en Argentina impregnándose de visiones gauchas... y en sus páginas (Risaralda) perpetuó al vaquero colombiano, hermano del gaucho argentino, aunque de menor categoría como expresión folklórica. Se diría que el ambiente fiestero huele más a mate que a guarapo." AF, 88 .

Contiene muchos argentinismos. Véase: Latcham, 10-13; Wade, 480-481.

Avella Mendoza, Temís'tocles (Sogamoso 1841-1914)

Los tres Pedros, en El mosaico (Bogotá), III, 1864, 93 et passim.

"... sirviéndole de asunto ... una crónica del Carnero, sobre sucesos que ocurrieron en Tunja en el siglo xvı." LA, 62.

Anacoana (Novela histórica). Bogotá, Imp. Constitucional, 1865, 29. BN.

Escrita expresamente para la "Semana literaria" de El conservador (Bogotá).

El sitio de Cartagena (Novela histórica), en Labor intelectual (Bogotá, Tip. Mercantil, 1915, vin-264. Pról. H. I. C. T.), 103-133.

Fechada 1862. 
Publio (Novela histórica), en Labor intelectual (1915), 134-198.

Fechada 1862.

Advertencia: "Aparte de las formas que exige la novela, seános permitido disfrazar esta historia con algunas adiciones de fantasía y con cl cambio de los nombres de sus personajes, pues lo reciente de los acontecimientos que se narran, nos retrae de dibujar estos cuadros con su histórica desnudez, y nos obliga a omitir nombres propios que por ahora debe el novelista respetar, por no herir la susceptibilidad de algunos de los que los llevan, ni ofender la modestia de los héroes de la narración. Si, pues, se pide fidelidad a la historia, concédase a la novela su ficción y disfraz, conservando sí, en éste y aquélla, la verosimilitud." El autor, febrero de 1862 .

Daniel Sikles.

Citada por LA, 62, que no da ni lugar ni fecha de publicación.

"... personaje que visitó a Bogotá, y cuya trágica vida, rápidamente narrada en El iris, por J. J. Borda, dió pie ... para su novela, inventando sólo el final ..." LA, 62.

LA considera las novelas Anacoana, Eaniel Sikles, y Los tres Pedros, junto con su libro de viajes a Europa, "sus trabajos más importantes."

Azur, Exí (Véase: Gutiérrez, Pablo Emilio)

Barco, Jesús María

Susana i Mercedes. Bogotá, Imp. Gaitán, 1876, 210.

Véase: LA; 66 .

Barra, Casimiro de la (Véase: Soto Borda, Clímaco)

Bautista, Ramón María

Rojo y azul (Novela sobre la tragedia política en Colombia). Cúcuta, Edit. Cervantes, 1936, Iv-268. Pról. El autor. LC.

Si tuvieras una bija (Novela), Cúcuta, 1943. Citada por Cat. Libr. Colombiana, 1945.

Expiación (Novela). Citada por Cat. Libr. Colombiana, 1945.

En prep. Sangre $y$ miseria. (Novela). 


\section{Bayona, RaFael}

Amor de hija, en El rocio (Bogotá); -, en Horas de solaz (San José de Costa Rica).

Citada por Cortázar, "Apéndice."

Bayona Posada, Dantel (Bogotá 1886-1919)

Pasiones (Novela). Madrid, Saturnino Calleja Fernández, s. f., 223. Ils. Bibl. Calleja: 171. BN.

Véase: Ladrón, 466-467.

Bayona Posada, Daniel y Gómez Corena, Pedro (seud. Rodrigo de Rahavánez)

Contrastes (Novela histórica de costumbres bogotanas). Bogotá, G. Forero Franco, 1905, xxv-274. Pról. R. Escobar Roa. LAC Y.

“.. la primera producción novelesca (del autor) ... una verdadera novela de costumbres nacionales." Pról.

Caprichos. Escenas de la vida intima '(Novela colombiana). Barcelona, F. Granada y Cía., 1907, 154. Bibl. de autores americanos. LAC. LC Y.

Véase: Cortázar, 29-30.

\section{Bernal, Alirio}

Para publicarse: El iceberg.

"... novela de trama psicológica, en un plano universal."

Anunciada en la prensa bogotana, en 1947.

Bernal Orjuela, Raimundo (seud. Beta) (Cundinamarca)

Viene por mi i carga con usted (Travesura histórico-novelesca de un curioso desocupado) (R. B. O.). Bogotá, "El núcleo liberal," 1858, 209. LAC.

"La novelita apuntada, cuadro de costumbres muy bogotanas, es a modo de amarga y viva censura contra cierta clase de mujeres rezanderas que en ... (1858), hacian insufrible la vida bogotana..." LA, 73. 
Véase también J. M. V (ergara) y V(ergara), en El mosaico (Bogotá), $x, 139-140$.

Bertildo (Véase: Acosta de Samper, Soledad)

Beta (Véase: Bernal Orjuela, Raimundo)

Branco, Roberto (San Antonio de California 1894- )

La estatua (Novela corta).

Citada por Ospina, 292.

Borda, José Joaquín (Tunja 1835-1878)

Koralia, en El mosaico (Bogotá) (Cortázar, "Apéndice"); 一, Bogotá, Libr. Nueva, s. f. [1899]. Bibl. popular: 144-145. BN; ibid., 1916, 113-176. Y.

Morgan el pirata, en El mosaico (Bogotá); -, en El pasatiempo (Bogotá).

Citada por Cortázar, "Apéndice."

Botero, Juan José (Rionegro 1840-1926)

Lejos del nido. Medellín, Tip. Helios, s. f. [¿ 1924 ?]; 329.

Novela de costumbres.

Botero Guerra, Camilo (seud. Don Juan del Martillo) (Medellín 1853 - )

De paso (Novela).

Citada por Cortázar, "Apéndice."

Sacrificio (Novela).

Citada por Ortega, 1025.

Botero Restrepo, Jesús (Antioquia 1921- )

Andágueda (Novela). Bogotá, "Teoría," s. f. [1947], 208. 
Narración novelesca de las aventuras del autor entre los indios del Andágueda.

Botero Saldarriaga, Roberto (seud. Zoilo Expedito) (Antioquia 1871 - )

Sangre conquistadora. Medellín, "La organización," 1911, 122. LAC.

Uno de los catorce mil. Medellín, Tip. Industrial, 1922, 276. Ils. LAC Y.

Véase: Wade, $477-478$.

Bretal, Máximo (Véase: Castro, Dr. Alfonso)

Briceño, Manuei.

La nube errante (Novela de costumbres). Bogotá, Cromos, 1924, 202. BN LC.

"La nube errante es una vida, cualquier vida, toda vida, sometidos como están los hombres al capricho de escondidas deidades..." L. E. Nieto Caballero, Libros colombianos publicados en 1924, 149-1s3.

En prep. Sangre azul (Novela).

Bueno R., JoAquín

Amor sin fe, en El rocío (Bogotá).

Citada por Cortázar, "Apéndice."

Pablo, en El rocío (Bogotá).

Citada por Cortázar, "Apéndice."

Buttrago, Francisco L.

Lucha de clases. Ibagué, Edit. Santafé, 1932, 192. Pról. F. López Giraldo. BN,

"... no es un libro con intenciones literarias sino con finalidades sociales ... breviario trágico... que tiene más impulso demoledor que la dinamita ... libro de ... bella intención proletaria ..." Pról. 
Buttraco, Jaime

Pescadores del Magdalena. Bogotá, Minerva, 1938, 237. Vocabulario: 231-237. D LC NC.

Una enciclopedia más bien que una novela. Véase: Latcham, 16-19.

Hombres trasplantados (Novela de colonizaje). Manizales, Imp. Departamental, 1943, 228. BN LC.

Trata de la colonización del Quindío de hace menos de un siglo.

Caballero Calderón (Swann), Eduardo (Bogotá 1910- )

Almas débiles (Novela). Bogotá, (Bibl. de los últimos: 3), s. f. [8 1935 ?].

Tipacoque. Estampas de provincia. Bogotá, Edit. Mundo al día, 1941, 279. LC; -, Buenos Aires, Club del Libro ALA, 1942, 181. Nota biográfica. LC.

"Novela campesina del altiplano boyacense, región de leyenda de tipos curiosos, y con estampas provincianas que son trasunto fiel del alma agraria de los páramos." OM, Hist., 249.

Véase: AF, 89-90; Luis Durand, Atenea (Chile), Lxx, 208, octubre, 1942, 143-145; Latcham, 21-25.

El arte de vivir sin soñar (Novela). Bogotá-Medellín, Libr. Siglo XX, 1943, 230. Ils. Rivero Gil. BPC.

Caicedo, Juan Esteban

Julia (Obra de costumbres nacionales, tolimenses), Bogotá, Luis M. Holguín, 1901, 111. BN.

"De amores honestos, tristes al fin." Ladrón, 111.

Caiceno, Rodolfo (¿Panamá? 1868-1905)

La Pola (Novela). Cartagena [¿ 1890 ?].

"... en 1890 se anuncia la publicación próxima, en Cartagena, de La Pola, novela de Rodolfo Caicedo (1868-1905), que no sabemos si en realidad se editó." Rodrigo Miró, Orígenes de la literatura novelesca en Panamá, Panamá, Imp. Nacional, 1948, 21. 
Carcedo Rojas, José (seud. Celta; Yarilpa) (Bogotá 1816-1898)

Don Alvaro (Cuadros históricos y novelescos del siglo xvI), en $R e$ vista de Bogotá, agosto de 1871 a julio de 1872; -, en Escritos escogidos de José Caicedo Rojas (v. Ir. Bogotá, Medardo Rivas, 1891, 292. BN Y).

Véase: Cortázar, 40-46; LA, 89-90; OM, Hist., 237.

Los amantes de Usaquén, en Apuntes de rancheria (Le Havre, 1871, 183 ); -, Bogotá, Libr. Nueva, s. f. [c 1899 ?]. Bibl. popular: 150; ibid., s. f. [z $191 \ldots$ ? $], 309-339$. Y.

Citada como "novelita" por LA. "Algunos de sus cuadros están recogidos en el ya mencionado volumen Apuntes de rancheria -en donde están la novelita Los amantes de Usaquén y El tiple-_." Ortega, 202.

Cristina, en El repertorio colombiano (Bogotá), v, 1880, 129-162.

Citada como "novelita" por LA, 89-90.

La bella encomendera, en El repertorio colombiano, x, 1883-1884, 474-494.

Citada como "novelita" por LA, 89-90.

El cacique don Diego de Torres, en El repertorio colombiano.

Citada como "novelita" por LA, 89-90.

Juana la bruja (Novela histórica), en El telegrama (Bogotá), 1894;

-, Bogotá, "El telegrama," 1894, 136. BN LAC.

Véase: Ladrón, 112.

La espada de los Monsalves, en El repertorio colombiano.

Véase: Ortega, 202.

El maestro de baile, en El repertorio colombiano.

Véase: Ortega, 202.

Mis aguinaldos!, en El repertorio colombiano.

Véase: Ortega, 202.

Martin Penulero, en El repertorio colombiano.

Véase: Ortega, 202. 
"De lo mejor de su pluma son las once novelas históricas que - por el estilo de Don Alvaro- publicó en El repertorio colombiano, de las cuales son dignas de mencionarse: La espada de los Monsalves, Mis aguinaldos!, Cristina, Martin Perulero, El maestro de baile y El cacique don Diego de Torres. También hay que recordar Juana la bruja. En cuanto a la parte genuinamente histórica de estas novelas, Caicedo Rojas se apoyó en las crónicas de Rodríguez Freyle, y por eso cayó en algunas inexactitudes." Ortega, 202.

Calonge Puche, Evaristo

Plinio y Amelia. Barranquilla, Lit. Barranquilla, 1944, 166. BPC.

"... la descripción fidedigna de un idilio que floreció entre perfumes, brisas y ternuras ... aromadas con la dulce poesía de la inocencia." Texto.

Camacho de Figueredo, Pomiana (Vélez 1841-1889)

Escenas de nuestra vida. Bogotá, Nicolás Pontón, 1873, 11 s.

Camargo, Esther S. de

De vuelta (Novela de costumbres regionales).

Novela inédita de 200 páginas, anunciada por "La cabaña" de Bucaramanga.

Canal Ramírez, Gonzalo

Leonardo. Bogotá-Medellín, Libr. Siglo XX, 1944, 273. BN.

Carazo For tich, R.

Los ilegitimos (Novela). Cartagena, "Calamary," 1946, XI-199. Pról. El autor. BPC.

“... una novela cuyo argumento he arrebatado a la vida armándome de audacia y de coraje. Quizá he sido demasiado cruel con mis personajes coloreando muy fuerte sus instintos y pasiones; pero esa es la vida...!" Pról.

Ilusión de campesina (Novela).

Anunciada por Edit. "Calamary." 
Misia Robustiana (Novela).

"Un girón de la vida diaria ... del primer novelista de la Costa." Anunciada por Edit. "Calamary."

Altagracia (Novela).

"Drama fuerte de hombres valientes e intrigas de caciques provincianos." Anunciada por Edit. "Calamary."

Cárdenas Roa, María (seud. Luz Stella) '(Bogotá 1900- )

Pétalos (inédita), 'en La novela semanal, I, 23, 28 de junio, 1923, 243-251. BN Y.

La llamarada (Novela corta), en La novela semanal [¿ 1923 ?]

Sin el calor del nido (Novela corta), en La novela semanal [: 1923 ?].

Los celos del río (Novela), en Santafé y Bogotá, iv, 1924, 343-363.

Véase: Ospina, 466.

Carrasquilla C., Luis

Abismos (Novela. Ensayo biológico-social). Bogotá, Edit. Santafé, 1932, x-153. Pról. Jorge Anzola Casseres. LC.

“... novela de ambiente bogotano, real, descriptiva, de tamiz picaresco... el primer ensayo sociológico de Carrasquilla, vinculado a hondos principios biológicos..." Pról.

En prep. Mujer y sombras, "Novela intensa, de costumbres antioqueñas y bogotanas, de principios biológicos y sociales y de crítica razonạda."

Carrasquirla, Tomás (seud. Carlos Malaquita) (Antioquia 1858-1940)

Frutos de mi tierra. Bogotá, Libr. Nueva, 1896, xxuI-413. Pról. Pedro Nel Ospina. LAC LC Y; -, editado bajo el título de Tipos colombianos (Edición mimeografiada). Salt Lake City, University of Utah, s. $f$. [¿ 1948 ?]. 2 v. IX-124-(40). Pról., adapt. y vocabulario: Enrique C. de la Casa y Madge Howe.

Véase: Cortázar, 68-74; Carlos García-Prada, "En acción de justicia a Tomás Carrasquilla," en Estudios bispanoamericanos (México, s. f.), 255-259; Wade, 472-473. 
Blanca (Novela corta), en El montañés (Medellín), 1897-1898; -, en El padre Casafús (1914), (véase abajo), 83-112.

En la diestra de Dios Padre (Novela corta), en El montañés, 18971898; -, en El Padre Casafús (1914), 115-135; -, en Novelas (1935) (véase abajo); 17-47; —, en Cuentos de tejas arriba (1936) (véase abajo), $7-44$.

Dimitas Arias (Novela corta), en El montañés, 1897-1898; -, en El Padre Casafuis (1914), 139-184; -, en Novelas (1935), 107-165.

El ánima sola (Novela corta), en El montañés, 1897-1898; -, en El Padre Casafús (1914), 187-202; -, en Cuentos de tejas arriba (1936), 45-73.

Salve, Regina. Medellín, Imp. Oficial, 1903, 95. LAC; -, en Entrañas de niño (1914), 159-199; -, Medellín, 1925; -, en Novelas (1935), 49-105.

Véase: Ladrón, 121-122.

Entrañas de niño (Novela), en Alpha (Antioquia), 1906; - (1914) (véase abajo), 1-134.

"... vió la luz en 1906 en varias entregas de Alpba, célebre revista literaria de Antioquia." Cortázar, 75.

Grandeza. Medellín, "La organización," 1910, III-383. Pról. T. C. BSM LAC LC Y; - (Novela). 2 ed. Medellín, Imp. Oficial, 1936, 378: Pról. T. C. D IC.

"No tiene esta obra tesis ni tendencia alguna; ni siquiera lo que se llama un concepto estético; me he propuesto únicamente acumular en una narración cualquiera notas, caracteres, y detalles de nuestro ambiente. Fuera de uno (Magdalena Samudio, dama harto distinguida en Medellín), ningún otro de los tipos... se refiere a persona determinada, como a tantas gentes se les suele suponer." Pról.

El Padre Casafuis (Novela). Medellín, Carlos E. Rodríguez E., 1914, 217. LAC Y.

Contiene las siguientes novelas cortas: El Padre Casafús, 5-79; Blanca, 83-112; En la diestra de Dios Padre, 115-135; Dimitas Arias, 139-184; El ánima sola, 187-202; San Antoñito, 205-217. 
Entrañas de niño (Novela). Medellín, Carlos E. Rodríguez E., 1914, 251. BSM Y.

Contiene: Entrañas de niño, 1-134; Simón el mago, 137-156; Salve, Regina, 159-199; y Homilias, 203-251.

El zarco (Novela). Bogotá, Ed. Colombia: 8, 1925, 216. D LC Y.

Ligia Cruz, Rogelio (Dos novelas cortas). Bogotá, Ed. Colombia: 13, 1926, 163. Ligia Cruz, 5-136; Rogelio, 137-163. D LC; Rogelio, en Cuentos de tejas arriba (1936), 175-209.

La marquesa de Yolombó (Novela del tiempo de la colonia). Medellín, A. J. Cano, 1928, 398. Pról. T. C., 5-13. BSM LC; -, Buenos Aires, 1945. Pról. "Carrasquilla y la novela en Antioquia," por Rafael Maya. Col. Panamericana.

Véase: Wade, 473-474.

Hace tiempos (Memorias de Eloy Gamboa). 3 v. Medellín, Atlántida, 1935-1936. BN LC NC T.

I. Por aguas y pedrejones, 1935, 331. Laureado con el Premio Nacional de Literatura de 1935.

II. Por cumbres y cañadas, $1935,337$.

III. Del monte a la ciudad, 1936, 306.

Novelas. Bogotá, Minerva, 1935, 165. Pról. 5-15. SSO: 20. BN LC T Y.

Contiene: En la diestra de Dios Padre, 17-47; Salte, Regina, 49-105; y Dimitas Arias, 107-165.

Cuentos de tejas arriba (Folklore antioqueño). Medellín, Atlántida, 1936, 219. D.

Contiene: En la diestra de Dios Padre, 7-44; El ánima sola, 45-73; El prefacio de Francisco Vera, 75-92; El gran premio, 93-111; Simón el Mago, 133-150; San Antoñto, 151-173; Rogelio, 175-209; y Palonegro, 211-219.

Carreño, Gabriel

Disloques (Crítica de costumbres y apuntes frívolos de ambiente regional). Bucaramanga, "La cabaña," s. f. (1936), 294. LC. 
Castañeda Aragón, Gregorio (Santa Marta 1886- ')

Náufragos de la tierra, en La novela semanal, 1, 3, 8 de febrero, 1923, 21-31. BN Y; -, Bogotá, Minerva, 1936, 89-111. Pról. Samper Ortega. SSO: 20. BN LC T Y.

“... una preciosa novela social... que tiene el mérito de ser precursora del problema que hoy desvela a los legisladores, atemoriza a los latifundistas y sirve de pretexto ... digámoslo francamente... a diversos profesionales de la agitación, para esquilmar a los labriegos o alcanzar posiciones políticas." Pról.

Zamora, en La novela semanal, s. f. (1923).

Citada por Samper Ortega, "Prólogo" a Náufragos de la tierra.

\section{Castellanos, Luis Alberto (Sutamarchán)}

Jenny (Novela colombiana). Bogotá, Tip. Voto Nacional, 1932, 215. LC.

Los amores de Ramiro con Jenny, con incidentes bastante fantásticos de la alta sociedad bogotana.

Castells, José María (Véase: Gallego, Romualdo)

Castrimlón Arboleda, Diego (Popayán 1920- )

José Tombé (Novela folklórica). Bogotá, Antena, 1942, 183. Pról. Guillermo Valencia. Vocabulario: 181-183. LC.

Primera novela del autor. "El relato en sí mismo es de actualidad y tiene un marcado carácter sociológico. Trátase del viejo tema que cxpone la sorda lucha existente entre los antiguos pobladores de América..."Pról.

Sol en Tambalimbú (Novela). Bogotá, Edit. Kelly, 1949, 314. Glosario.

De ambiente social, el blanco, el mestizo y el mulato enfrentados.

Para publicarse: Jooba (Novela autóctona colombiana).

Susana (Novela social, nuestra). 
Castro, Dr. Alfonso (seud. Máximo Bretal) (Medellín 1878-1943)

Vibraciones (Cuentos y novelas cortas). Medellín, Imp. Oficial, 1903, xxiv-157. Pról. F. Cano. Y.

Hija espiritual (Novela). 2 ed. Bogotá, Tip. Popular, 1906.

Dos ediciones: "El doctor Alfonso Castro alborotó el cotarro a su turno en 1906 con Hija espiritual, no ya por un asunto de masas, sino de personajes que la suspicacia localizó en el vecindario, lo que dió auge al libro y no pocas molestias al autor. Desde Hija espiritual hasta El señor doctor, la más calificada de sus novelas, hay una activa producción con Los bumildes y De mis libres montañas, las más populares.” AF, 77.

Véase: Cortázar, 97-100.

Los bumildes, Medellín, Imp. Medellín, 1910, 366. LAC Y.

Véase: Ladrón, 127.

Abismos sociales. Medellin, Imp. Medellín, 1912, 103. LAC.

Véase: Gómez, Alfonso Javier, nota.

Justicia, en La novela semanal, $x, 14 ; 26$ de abril, 1923, 145-154. BN Y. BSM.

El señor doctor (Novela). Medellín, Tip. Industrial, 1927, 466.

De mis libres montañas (Cuentos y novelas cortas). Medellín, Libr. y Tip. Búffalo, 1931, 211. LC.

Diez cuentos, o novelas cortas, antioqueños y realistas, de un humorismo irónico y burlón.

Clinica y espiritu (Novela). 2 ed. Bogotá, Edit. ABC, 1940, 434. D LC.

Experiencias de un joven médico.

Para publicarse: Como en tiempos de Calixto y Melibea (Novela).

Véase: Velázquez, Samuel, bajo Madre.

Celta (Véase: Caicedo Rojas, José) 
Cervantes, Pedro Pablo (Bogotá)

Recuerdos del bospital militar (Cuadro histórico número xxv: Un recluta). Bogotá, Echeverría hnos., 1878, 50. Pról. El autor. BN.

"... preferencia a los Recuerdos del bosfital militar trazados en varios Cuadros que empiezan desde la época de mi infancia ... El presente cuadro ("Un recluta"), como todos los otros, fué escrito hace diez y siete años." Pról.

Recuerdos del bospital milatar tiene más animación y viveza de colorido, como obra de imaginación, que ... La suerte de un santafereño ... en la cual narra las desventuras y dolores que experimentó uno de los soldados de Nariño en la campaña de Pasto." LA, 114.

LA llama Recuerdos del bospital militar una novela corta. Dice que La suerte de un santafereño fué publicada en un periódico.

La suerte de un santaffereño, en El repertorio colombiano (Bogotá), vi, $1881,343-409$.

Cocherín, IváN

Esclavos de la tierra. Manizales, Imp. Oficial, s., f. [i 1945 ?], 125. BN.

Dedicatoria: ". . Para toda esa clase campesina, carne de cuartel, de hospital y de urna van estas 'páginas fraternales."

Compadre Tigre, EL (Véase: Samper Ortega, Daniel)

Contreras Daza, Antonio

Sobre el lomo del rio, en La novela semanal, 1, 13, 19 de abril, 1923, $135-143$. BN.

CORONEL, JUAN

Un peregrino. Guatemala, Tip. Moderna, 1895, 303.

Correa de Rincón Soler, Evangeitina (Tunja)

Los emigrados (Leyenda histórica). Bogotá, Medardo Rivas, 1869, III108. LAC. 
Escrita en 1867. Según el prólogo el relato es rigurosamente histórico. "...la historia de dos jóvenes esposos de la Colonia, que ... vieron combatida de improviso su felicidad por los azares de la guerra de Independencia, en la cual tomó parte el esposo, enrolándose en el ejército patriota que se organizó en los llanos de Casanare ... La autora dedica las mejores páginas... a la pintura del viaje de la caravana desde el pueblo de la Salina de Chita hasta los caseríos de los llanos de Casanare." LA, 120-121.

Cortés, Enrique (Tunja 1838-1912)

Escritos varios, 2 v. París, Imp. Sudamericana, 1896. LC Te.

El primer tomo contiene siete novelas cortas, y unos ensayos de caracter variado.

Cortés, Francisco de Paula (Bogotá 1850-?)

Amores de dos especies (Novela histórica). Popayán, Imp. del Colegio Mayor, 1868.

Luisa Norval, en Cuadros de un pintor bogotano. (Bogotá, Imp. de Gaitán, 1881, 112).

Una novela corta.

Cuéllar, Adolfo

Margarita

Citada por Cortázar, "Apéndice."

El hombre inédito

Citada por Cortázar, "Apéndice."

\section{Cuéllar Chaves, Z.}

La penúltima nocbe (Proceso patológico de un suicidio normal). Bogotá, Minerva, 1935, xI-313. Pról. El autor. LC.

“. . me ha sido desde luego imposible ceñirme en absoluto a la realidad. Algunos pasajes he tenido que reconstruirlos... cambiando... aquellos -en especial los lugares y los nombres- que permitirían identificar a mis personajes ... Pero esto, que podría constituir la parte novelesca del relato, no altera en nada la esencia, el interés ni la enseñanza." Pról. 
Cuervo, ANgel (Bogotá 1838-1896)

Jamás. París, "Europa y América," 1892, xI-196. Bibl, de la Europa y América; - 2 ed. París, Casa del autor, 1893, xI-204. LAC.

Véase: Laverde Amaya en Revista literaria (Bogotá), Ix, 381-386.

". . mereció ser traducida al francés por madame Marguerite du Lac ..." OM, Hist., 239. Publicada en Le monde latine et le monde slave.

En la soledad (Novela americana). París, "Europa y América," 1895.

Dick. París, Vda. de Victor Goupy, 1895, 192. LAC.

"El autor no se atrevió a llamar novela la que publicó con el nombre de Dick, porque tanto las proporciones de la obra como el asunto, apenas alcanzan a los límites de un cuadro de costumbres escrito con prolijidad de detalles.”' LA, 126.

Cuervo Márquez, Emilio (Bogotá 187.3-1937)

Pbinées. (Tragedia de los tiempos de Cristo). Bogotá, "La luz," 1909, 301. LAC LC Y; -, París, Paul Ollendorff, s. f., 292. LAC.

Véase: Ladrón, 153-154.

La ráfaga, en El nuevo tiempo literario (Bogotá), virr, 36-38, 27 de febrero, 1910, 562-595. BN; -, en Lili-La ráfaga-La selva oscura (Bogotá, Cromos, s. f. [¿ 1924 ?], 176. Y), 21-113.

En la portada de sobretiro de La ráfaga, hay esta nota firmada por el autor en marzo de 1922: "No quiero que la novelita publicada a continuación sea reproducida nunca. Ella ha sido rehecha por mí con el título de 'Corazón de mujer' y hace parte de mi colección de novelas cortas con argumento bogotano." Propiedad de LAC.

Lilí, en La novela semanal, 1, 1, 25 de enero, 1923, 1-9. BN; -, en Lilí-La ráfaga-La selva oscura (¿ 1924 ?), 3-18.

La selva oscura, en Lili-La ráfaga-La selva oscura (¿ 1924 ?), 117176.

Con respecto a La ráfaga, Lili, y La selva oscura, Eduardo Castillo dice: "... no son novelas propiamente dichas. Son ... lo que los franceses llaman nouvelle, y los españoles novelín ... Afírmase que nuestra vida social, pobre en aspectos, no le ofrece al novelista un campo suficiente- 
mente vasto para explayar su observación. Cuervo Márquez ha comprobado ... que esta apreciación es inexacta ..." Cromos, xxi, 503, 24 de abril, 1926.

\section{Cuesta, Rómulo}

Tomás. Bogotá, Cromos, 1923, 261.

Chapelet, Publio (Véase: Obeso, Candelario)

Chaverra, Gaspar (Véase: Vélez Barrientos, Lucrecio)

Chaves; Guillermo Edmundo

Chambú. Manizales. Bibl. de escritores, 1946, 387.

Rica en localismos. Véase: Boletín del Instituto Caro y Cuervo, II, 3 septiembre-diciembre, 1946, 559.

Dagua (Véase: Guarín, José David)

David (Véase: Guarín, José David)

D'AvigNoN, LAURA (Véase: Jaramillo Gaitán, Uva)

Dávila de Ponce de León, Waldina (seud. Jenny) (Neiva ?-1900)

El trabajo. Bogotá, Antonio María Silvestre, 1884, 157; -, en Serie de novelas (Bogotá, Antonio María Silvestre, 1892, 378), 5-159. BN LAC LC.

Véase: Ladrón, 165.

Luz de la nocbe, en Serie de novelas (1892), 163-290.

La muleta, en Serie de novelas (1892), 293-378.

Véase: Ladrón, 165-166.

Díaz (Castro), Eugenio (Soacha 1804-1865)

Una ronda de don Ventura Abumada. Bogotá, "La nación," 1858 , 44 ; - en SSO: $23,11-37$. 
Manuela (Novela original), en El mosaico (Bogotá), I, 186 et passim (inconclusa) 1861; -, Bogotá, Fación Mantilla, 1866, 278. Museo de cuadros de costumbres: 2; - (Novela de costumbres colombianas). París, Garnier, 1889, 2 v. xvi-284-242. Pról. Salvador Camacho Roldán. Ch LAC LC NC Te Y; -, Bogotá, Edit. Kelly, s. f., 455. BPCC, Novela: 3. LC T; - en SSO: 23, 73-154.

Escrita en 1858. Publicada también en El mosaico (Bogotá), t, et passim, pero sólo hasta el capítulo vir inclusive. ". . pinta, pues, únicamente las costumbres rurales del declive de la cordillera oriental de los Andes ... territorio en que el cultivo de la caña de azúcar y la fabricación de melazas y panelas, formaban hasta hace pocos años la industria casi exclusiva de sus moradores... La escena pasa en los años de 1856 a 1857 ... algo de esta lucha de las ideas de ese tiempo se encuentra también... En la Manuela se ha levantado la primera voz... [en contra] del robo de la inocencia, al sacrificio de la honra..." Pról.

"... deberá sobrevivir a través del tiempo y del espacio, como el mejor producto del ingenio criollo en el estudio pintoresco de las costumbres provincianas." OM, Hist., 232.

Véase: Cortázar, 7-12; Wade, 470-471.

Pioquinta, o el valle de Tenza (Novela histórica), en El bogotano (entre 1863-1866, inconclusa); 一, Bogotá, 1873.

El rejo de enlazar. Bogotá, "La América," 1873, 296. BN; -, Bogotá, Edit. Kelly, 1942, xir-232. Pról. Tomás Rueda Vargas. BPCC, Novela: 1. LC; -2 ed. $1944, x-246$.

Escenas de la vida de la sabana bogotana por los años de 1840-1850.

Los aguinaldos en Chapinero. Bogotá, "La América," 1873, 324. Bibl. "La América." LAC.

Bruna la carbonera. Bogotá, Eustacio A. Escobar, 1878; -, en El bien social (Bogotá).

Publicóse también en $E l$ bien social. Anúnciase una serie de "Novelas de costumbres nacionales": I. Bruna la carbonera; II. Manuela; III. María Ticince; IV. Una ronda de don Ventura Abumada; V. Los aguinaldos en Chapinero; VI. El rejo de enlazar; y VII. Juan el expósito. 
Díaz Guerra, Alrrio (Tunja 1862- )

Lucas Guevara. New York, Y'ork Printing Company, 1914, 315. Foto. LAC.

Para publicarse: La parroquia (Novela).

May (Novela-estudio social).

Echeverría, Eduardo (Bogotá 1873-1948)

Garza morena (Novela).

Citada por Ospina, 712 .

Emuro (Véase: Mejía, Epifanio)

Escobar, Emilio ANtonio (Bogotá 1857-1885)

Aurelio (Novela). Inédita.

La novia del Zipa (Novela). Inédita.

"Dejó sin publicar varios trabajos filosóficos, un tomo de poesías y otro de cuentos fantásticos, fragmentos de un drama intitulado El infierno de los santos, y dos novelas, La novia del Zipa y Aurelio." Ospina, 735 .

Escobar Alzate, Ramón BPB.

Esther de Roncesvalles (Novela). Bogotá, Libr. Leticia, 1944, 182.

Roncesvalles, Tolima, tierra agrícola y ganadera de gran futuro; novela regional que define "un interesante temperamento femenino."

Escobar Roa, Rafael (Chía, 1879_ )

Lo que contó el patojo. Bogotá, Edit. ABC, 1941, 208. BPB.

Escobar Uribe, Jorge (seud. Claudio de Alas).

Fuego y tinieblas, o El drama de la legación alemana (Novela real). Santiago de Chile, Zig-Zag, 1909, 222. Ils. Raúl Figueroa (Chao). Y. 
"Un relato novelesco sobre el famoso drama de la legación alemana de Chile. Causó espanto. Es una novela policial donde la imaginación del poeta traza cuadros horribles, en estilo claro..." Pról. a La herencia de la sangre.

La berencia de la sangre (Novela póstuma). 4 ed. Buenos Aires, A. Escobar Uribe y P. Ventriglia y Cía., s. f. [i 1919 ?], 223. Pról. Juan José de Soiza Reilly, 7-12. LC.

Espinosa, Antonio R.

Insondable (Novela). Bogotá, Imp. Eléctrica, 1907, 346. LAC.

Véase: Ladrón, 206.

Espinosa de Rendón, Silveria (Sopó 1815-1886)

"Cultivó la novela..." Ortega, 181.

FABo, Fr. Pedro (España 1873- )

El doctor Navascués (Novela de costumbres casanareñas). Bogotá, Libr. Nueva, 1904, 150. LAC.

"Novela premiada."' Ospina, 766.

Amores $y$ letras.

"Novela premiada." Ospina, 766.

Corazón de oro.

"Novela premiada." Ospina, 767.

Fisgón, El (Véase: Guarín, José David)

Flórez, Luis Carlos

Llamarada. Montenegro, 1944.

"Novela obrera." Cat. Libr. Colombiana, 1945.

Forero Franco, Guillermo

La parroquia (Novela). Nueva York, Polyglot Printing and Publishing Co., 1911, 171. LAC NC Y. *

"Condenada bajo pecado mortal ..." Ladrón, 231. 
Franco Vargas, Constancio (Vélez 1842-， )

Fragmentos de la vida de Ester. Bogotá, Imp. del Estado, 1864, 40.

Policarpa (Novela histórica). Bogotá, Zalamea hnos., 1890, 223. Y.

La vida y muerte sacrificial de la joven patricia Policarpa Salabarrie$\mathrm{ta}$, en la guerra de independencia colombiana.

Galán el comunero (Novela histórica). Bogotá, Zalamea hnos., 1891, 265. LAC Y.

La vida y el suplicio de José Antonio Galán, uno de los comuneros cuya agitación revolucionaria dió principio a la república colombiana.

Franky G., Guillermo (Cartago 1904- )

Cepas de la aristocracia (Ensayo de novela crítico-satírica). Bogotá, Imp. del Comercio, 1919, 54. Pról. El autor. Foto. LAC.

Amelia. Bogotá, Cromos, 1924, 121. BN.

Los misterios de Bogotá o Los bijos de Némesis. Bogotá, Cromos, 1925, 238. BN.

Anuncia: Noviciado del matrimonio (dos tomos inéditos).

Franky G., Ramón (Cartago, 1878- )

Mariana (Novela original). Bogotá, "La prensa," 1917, 92. LAC.

Anuncia: Susana (inédita).

Fuenmayor, José Félix.

Cosme (Novela). Bogotá, Cromos, 1927, 324. Pról. Rafael Sánchez Santamaría. BPB.

Fechada: Barranquilla, diciembre de 1926.

"... mucho sabor local barranquillero... (pero) los desventurados protagonistas (inclusive Cosme) son tipos que se encuentran en todas las latitudes." Pról.

Una triste aventura de 14 sabios (Cuento fantástico). Barranquilla, Edit. Mundial, 1928, 107. LC.

Podría clasificarse como novela. 
Gallego, Romualdo (seud. José María Castells) (Antioquia 1895-1931)

La pródiga avaricia (Novela), en Crónicas, cuentos y novelas de Romualdo Gallego (Medellín, Imp. Oficial, s. f. [i 1935 ?], 556. Recopilación hecha por Margarita Cárdenas V. de Gallego y Pedro A. Gallego T. Foto. Conceptos de Tomás Carrasquilla, Francisco Villaespesa, Gonzalo Restrepo Jaramillo. D LC) , 186-215.

La pródiga avaricia ganó el Premio Unico del Torneo Literario en los Juegos Florales de Medellín de 1925.

Ricos vergonzantes (Novela de costumbres antioqueñas), en Crónicas, cuentos y novelas de Romualdo Gallego, 428-465.

El sabor de la vida (Novela), en Crónicas, cuentos y novelas de Romualdo Gallego, 466-556.

Galvis R., Eduardo

Rebeldía (Obra dedicada a la clase media, al obrero y al campesino). Bogotá, Minerva, s. f. [1944], 433. BN.

Gamboa, Francisco Antonio (Cali 1866-1908)

Victrix.

"Dejó varias obras inéditas, entre ellas su novela Victrix, de la que apenas publicó fragmentos." Ospina, $\$ 1$.

Gamboa, Isaías (Cali 1872-1904)

La tierra nativa (Novela). Santiago, Chile (véase: Ospina, 52); Tierra nativa, Cali, 1944 (reimpresión).

"Novela terrígena escrita en el Valle del Cauca por el famoso poeta muerto en Chile hace más de 40 años." Cat. Libr. Colombiana, 1945.

“... y editó la novela La tierra nativa, en que pinta sus propios dolores y nostalgias, con pulcro y animado estilo, en magníficas páginas descriptivas." Ortega, 504 .

\section{García González, Gilberto}

El clérigo y el hombre. 1 ed. Barranquilla, Tip. Escofet, 1940, 214. Pról. Dr. J. Quintero Quintero. BPB; - 2 ed. Bogotá, Edit. ESF., 1941, v-168. BPB. 
“.. hay en sus páginas un profundo sabor didáctico, de enseñanza, de filosofia, a tal punto que en ocasiones nos olvidamos de que es una obra novelesca." Pról.

Para publicarse: La voluntad (Novela).

Las guerras (Novela).

De buena familia (Novela).

La barabunda (Novela).

García Herreros, Manuel (Cartagena 1894- )

Lejos del mar (Novela). Barranquilla, Tip. Mogollón, 1921, 108. LAC Y; -, en SSO: 17, 19-79.

Un idilio juvenil.

Asaltos, en La novela semanal, I, 5, 22 de febrero, 1923, 43-53. BN Y.

Giarcía Herreros O., Alberto

Pedro Hernández (Novela) Bucaramanga, Imp. Departamental, 1947, 289.

García Llach, Antonto

Alma traidora. Hacia la gloria. Calamar, "Guante Blanco," $1922-$ 1924, 155 . BN.

Dos novelas cortas: Alma traidora, 7-50; Hacia la gloria, 51-155.

Gaviria, José Antonio (Antioquia)

Ernesto.

Novela corta premiada en un concurso celebrado en Medellín.

GebhardT, EMilio

La última nocbe de Judas, en La novela semanal, I, 10, 29 de marzo, $1923,103-111$. 
Giraldo, Francisco (Aguadas 1884-1926)

El bijo de la otra, en El bijo de la otra (Bogotá, Juan Casís, 1911, vir-138. BN LAC), 1-61.

Novela corta que da el título al libro.

Gnecco Mozo, José

Sabiduria melancólica (Nivola). Santa Marta, "El Estado," 1928, 143.

Gómez, Alfonso Javier (Medellín 1891-1916)

Madre glotona (Novela corta de costumbres campesinas). Medellín, Imp. Editorial, 1912, 131. BSM.

Novela galardonada con el Primer Premio en el Concurso Literario de Progreso. Contiene el Fallo del Jurado, firmado por César Piedrahita V., Antonio José Montoya y Carlos Mejía, el día 5 de julio de 1912. Juzgaron 43 obras, 21 en prosa, 22 en verso. Abismos sociales de Alfonso Castro (véase: página 24 de ésta) ganó el segundo premio. Citados entre otros cuentos y cuadros eran los siguientes: Cuadro sin marea, El machete dc A. Posada, Soledad, y Por un beso.

Gómez, Efe (Véase: Gómez Escobar, Francisco)

Gómez Corena, Luis (Bogotá 1884-1927)

Un redentor moderno, en La novela semanal, I, 21, 14 de junio, 1923, 221-230. BN Y.

Gómez Corena, Penro (Véase también: Bayona Posada, Daniel y ...)

(Bogotá 1882- )

Gizaña (Novela). Bogotá, Juan Casís, 1921, 268. Bibl. de la Sociedad Arboleda: 2. LAC LC Y.

Dedicatoria: "... pudiera desarrollarse en cualquiera de nuestros centros provinciales; ... (Villa-Ahumada) ... es el que tiene más sabor local, una vida más suya..." 
Gómez Escobar, Francisco (seud. Efe Gómez) (Fredonia 1873-1938)

Un Zarathustra maicero, en La novela semanal, I, 12, 12 de abril, 1923, 122-134. BN Y.

Mi gente. Medellín, Imp. Oficial, 1936; -, Medellín, Edit. Balmore Alvarez G., s. f. [c 1945 ?]. Bibl. Efe Gómez: 3.

Gómez JATME, AIFredo (Tunja 1880- )

Por un alma vengo, en La novela semanal, I, 4, 15 de febrero, 1923, 33-49. BN Y. firmar.

"... traducida al inglés." Ortega, 612. Dato que no se pudo con-

Bajo la mascara (Novelita). Vigo, "La nueva prensa," 1929, 75.

El explorador del infinito (Novela teatral). Vigo, "La nueva prensa," 1932, 105.

Gómez Jaime de Abadía, Herminia (Tunja 1862-1926)

Dos religiones, o Mario y Frinea. Bogotá, Ignacio Borda, 1884, 126.

Véase: LA, 173-174.

Del colegio al bogar. Bogótá, "El telegrama," 1893, 147.

Véase: LA, 173-174.

Gómez Pxcón, Rafael (Pamplona 1900- )

. 45 relatos de un burócrata, con cuatro paréntesis (Novela). Bogotá, Minerva, 1941, 261. BPB LC.

La vida del empleado público.

Gómez Victoria, Mercedes (Cauca)

Los hijos del misterio.

E. Palacios (véase: Misterios de la vida) se refiere a la novela.

Misterios de la vida (Novela histórica). Bogotá, "La nación," 1889 , xil-56. Pról. Luciano Rivera y Garrido. Firmada en Buga, el 26 de diciembre de 1888. Cartas entre la autora y Eustaquio Palacios. 
No se puede clasificar como "novela histórica." "Describir con los más vivos colores los terribles cuadros y las escenas conmovedoras que a cada paso presenta la vida de los desgraciados expósitos, es ya de suyo un móvil de los más recomendables... ¿Qué importa a la autora... que haya impropiedad de lenguaje e incorrección artística en su trabajo, si en cambio ha escrito un libro útil, porque moraliza y enseña?" Pról.

González, ERnesto (Bolívar 1899- )

Juan Grillin (Aventuras pintorescas de un niño antioqueño). Medellín, Imp. Departamental, s. f. [¿ 1944 ?], 355. Ils. Hernando Escobar. BN.

González, Fernando (Envigado 1895- )

Pensamientos de un viejo. Medellín, 1916, 198.

Mi Simón Bolivar. V. I. Lucas Ochoa. Manizales, "Cervantes," 1930, xv-309. Introducción: El autor. BN.

"En primer término, esbozaré la biografía de Lucas Ochoa, para que así entenderse mejor la que hizo de don Simón Bolívar... Una biografía no es otra cosa que las reacciones que los hechos y pensamientos de un hombre producen en que los contempla."

Para publicarse: V. II. El libertador.

Don Mirócletes. París, "Le livre libre," 1932, 252. Pról. F. G., 1-12. BSM LC.

"Un libro de ideas y paradojas originales, audaces y puestas en forma de novela desarreglada y mordaz." Cat. Libr. Colombiana, 1945. LC.

El maestro de escuela. Bogotá, Edit. ABC, 1941, 135. Pról. El autor.

"...trata de la descomposición del Yo, que es el ambiente... el valor artístico reside en las imágenes. E1 mérito sociológico está en la honrada narración de la vida del maestro de escuela, 'quinta categoría,' sueldo de cuarenta pesos al mes." Pról.

Anúncianse las siguientes biografías: El Padre Elias.

Sócrates.

Gaspar Francia. 


\section{Mabatma Gandhi.}

No se pudo verificar de qué género literario son las siguientes obras: Una tesis, El remordimiento, Cartas a Estanislao.

González, Pablo (Aranzazu)

Flecharroja.

"Tiene en preparación una novela que titula Flecharroja, novela pedagógica que tiene por objeto demostrar cómo se van desarrollando las facultades de un individuo salvaje, tomado del fondo de la selva hasta llevarlo a la civilización." Ospina, 228.

González Camargo, Fídolo

A caza de maridos, en La novela semanal, I, 25, 12 de julio, 1923, 263-271.

González Cortina (Véase: Silvestre, Luis Segundo de)

González de la Gonzalera, Gonzalo (Véase: Marroquín, José Manuel)

González Q., Alvaro (Mayor)

La última orden (Novela). Bogotá, Imp. del Estado Mayor General, 1944, 160. Pról: Enrique Santos. "Al lector:" El autor. BPB.

González T(oledo), Aureliano (Tolima)

Aventuras de un cocinero (Crónicas del Cauca). Bogotá, "La nación," s. f.

LA dice que el libro salió sin firma y sin año de publicación.

Gooding, G. (Véase: Ortiz, Melitón y ...)

Greiff, Guillermo de (Antioquia)

El cuarto frio. Medellín, Grisales hnos., s. f: 180. BSM. 
Guarín, José David (seud. Dagua, David; El Fisgón) (Quetame 1830$1890)$

Las bodas de un muerto. Bogotá, Imp. Constitucional, 1866, 34; en Artículos y novelas (Socorro, Imp. del Estado, 1872, 266. BN), 121 140 .

Véase: Ladrón, 266.

Ruth, en Articulos y novelas (1872), 181-227; -, en El porvenir de Nicaragua (Managua), 90, 20 de noviembre de 1884 .

Las aventuras de un santo (Novela). Bogotá, "El progreso," 1877.

Las tres semanas (Novela de costumbres), en La pluma (Bogotá); -, Bogotá, Medardo Rivas, 1884, 216. BN LAC; -, Bogotá, Edit. ABC, 1942, xIr-183. Pról. B. R. BPCC, Novela: 4. BN Ch LC.

"... una serie de cuadros... de las últimas fiestas de toros celebradas en la Plaza de Bolívar, en Bogotá, allá por 1874." Pról.

Se refiere a los "tres novelines, Las bodas de un muerto, Las aventuras de un santo, y Las dos Julias que dejó sin terminar." Véase: LA, 188-189.

Las dos Julias, en El bogar (Bogotá).

Según Cortázar, "Apéndice," Las dos Julias salió en El bogar y Las tres semanas en La pluma, pero ni la una ni la otra se publicaron integramente.

Las ruinas de mi convento.

Mencionada por Nepomuceno J. Navarro en su "Introducción" a Flores del campo (Socorro, Imp. del Estado, 1871) con referencia al poema de Guarín, "A la soledad," que "fué agregada a su novela Las ruinas de mi convento."

Guerrero, Benjamín

Dios en el hogar (Novela). Bogotá, "La luz," 1910, 410.

Guerrero Tascón, Luis María (Chocó 1892- )

Victimas del interés (Novela corta). 
Amor y desengaño (Novela corta).

Citadas por Ospina, 259.

Gutiérrez, Pablo Emilio (seud. Elí Azur) (Caldas 1865-1920)

Claveles de Beatriz (Novela corta).

Ofelia (Novela corta).

Manolo (Novela corta).

Oros y pergaminos (Novela corta).

"Estas novelas cortas fueron escritas para concursos literarios y todas fueron laureadas." Ospina, 302.

Gutiérrez Castrellón, Hernando

Las dos joyas.

"Novela de descripción realista de caracteres y costumbres colombianos. La vida en nuestros pueblos; el mecanismo de la política de la administración y de la sociedad." Cat. Libr. Colombiana, 1945.

Gutiérrez Ferreira, José Antonio

La abandonada, en La novela semanal, I, 24, 5 de julio, 1923, 253262.

Guzmán, Diego Rafael de (seud. Mendo Méndez de Mendoza) (Guaduas 1848-1920)

Resignación (incompleta), en La tarde (Bogotá), 1876; -, en Selección literaria de Diego Rafael de Guzmán (Bogotá, Imp. Nacional, 1922, x-327. Pról. Antonio Gómez Restrepo. LC), 3-34.

La cruz de mayo, en El zipa (Bogotá), 1878; -, en Selección literaria de ... (1922), 37-99.

“... sus juveniles ensayos novelescos ... los llamó 'Novelas ejemplares' en homenaje a ... Cervantes... y mezclando recuerdos de estas novelas [de Cervantes] y de la Galatea ... compuso las dos curiosas novelitas tituladas Resignación y La cruz de mayo, que merecen estudiarse como textos de lengua, como interesantes adaptaciones del giro cervantino a asuntos nacionales ... colocó la escena de $\hat{L} a$ cruz de mayo en las pri- 
mitivas montañas de Antioquia, y ... dió como fondo a Resignación la pintura, muy animada y vigorosa por cierto, de una de nuestras contiendas civiles..." Pról. Antonio Gómez Restrepo.

\section{Guzmán Cabal, Camilo}

El legionario. Bogotá, Escuela Tip. Salesiana, 1938, 176. Foto. BSM. H. P. DE P. H. (Véase: Silvestre, Luis Segundo de)

Henao Toro, Félix (Manizales 1900- )

Engeni la pelotari. Manizales, Imp. Departamental, s. f. [1935], 365. Prỏl. El autor. LC.

"Hasta donde mis noticias alcanzan ésta es la primera novela psicoanalítica que se escribe en español. He creído que el autor debía sentir, pensar, animarse con el espíritu de sus personajes; por eso los cambios de estilo, la confusión y las repeticiones que hay en algunos capítulos corresponden al estado mental de los protagonistas." Pról.

Hernández O., Blas

En Barataria (Novela de costumbres colombianas). Bucaramanga, "La cabaña," 1924, 308. LC.

Anúncianse: Misia Paca. Bucaramanga, "La cabaña."

Crisantemos. Bucaramanga, "La cabaña."

Gente bien. Bucaramanga, "La cabaña."

Herrera de Núñez, Priscila (seud. Paulina) (Riohacha)

Un asilo en la Goajira (Novela histórica), en SSO: 11, 109-150.

Fechada en Bogotá, diciembre de 1879.

Hinestrosa, León (Bogotá 1816-1880)

Rodríguez el ajusticiado, en El pasatiempo (Bogotá), 1851.

Dice LA, 201: "... novela que reprodujo el Diario de avisos y El Semanario de las provincias, de Caracas, y en 1852 el folleto Reformas constitucionales." 
Hurtado de Alvarez, Mercedes (Popayán 1840-1890)

Alfonso (Cuadros de costumbres). Bogotá, Medardo Rivas, 1870, II81. LAC.

"Novela... en la que pintó las sociedades payanesa y bogotana de mediados del siglo." OM, Hist., 294.

IBÁÑEZ, JAIME (Manizales 1919- )

No volverá la aurora (Novela). Bogotá, "Publicidad Aurora," 1943, 328. Pról. Andrés Holguín. BPB.

". . una novela trabajada sobre la materia poética y ... sobre una evidente realidad nacional, aún regional ..." Pról.

Cada voz lleva su angustia. Bogotá, Edit. Santafé, 1944, 336. Pról. El autor. LC; -2 ed. 1945.

Tema es "pérdida de la tierra ... por fuerzas naturales que al obrar indirectamente sobre el alma cobran un sentido misterioso..." Pról.

Donde moran los sueños (Novela). Bogotá, Libr. Siglo XX, 1947, 352. BPC.

IsAACS, JORGE (Cali 1837-1895)

Maria. Bogotá, 1867. Pról. J. M. Vergara y Vergara; - 2 ed. Bogotá, Medardo Rivas, 1869; - 3 ed. Bogotá, Medardo Rivas, 1878, IV-251. Pról. J. M. Vergara y Vergara (Bogotá, junio de 1867). Vocabulario. Y; Maria (Novela americana). México, F. Mata, 1878, 402. Conceptos: G. Prieto y J. Trejo. Y; -, Buenos Aires, Igón hnos., 1879. Pról. José Manuel Estrada; - Barcelona, "Artes y Letras," 1882. Pról. C. de la K. Ils. Alejandro Riquer; ibid., 1883, vmI-378; ibid., 4 ed. 1884, 388. C; ibid., 5 ed. 1886, 388. Ils. Alejandro Riquer y J. Passos. C; ibid., 6 ed. Barcelona, A. Simón, 1894, Bibl. "Artes y Letras"; ibid., 8 ed. Barcelona, Maucci, s. f. [1922], rrm-334. Pról. C. de la K. Ils. A. Riquer y J. Passos. Grabados: Thomas y Gómez Polo. Bibl. "Artes y Letras." BSM LAC; 一, México, 1886, 496. Ils.; -, Barcelona, D. Cortezo y Cía., 1886, Ils.; (Novela americana). 2 v. México, Octavio R. Spíndola y Cía., 1888, IX334. Pról. Guillermo Prieto; -, Madrid, 1894. Pról. J. M. Pereda; ibid., Madrid, 1899; - (Novela americana). París, Garnier hnos., s. f. [1894], 432. Pról. J. M. Vergara y Vergara, Ignacio M. Altamirano, Guillermo Prieto, y Justo Sierra. LAC; ibid., 1898; ibid., 1919. C; - (Novela americana). París-México, Vda. de Ch. Bouret, 1914, 385. LAC; ibid., 
1931, 590. Vocabulario: 587-590; - (Novela americana), New York, Ginn, s. f. [1918], xıv-209. Edit. R. H. Keniston. Ils.; - (Edición definitiva publicada de acuerdo con anotaciones, adiciones y correcciones del autor). Bogotá, Camacho Roldán y Tamayo, 1922, viII-430. Pról. J. M. Vergara y Vergara (Bogotá, junio de 1867). Vocabulario, 427-430. LC; - (Novela americana). New York, MacMillan, 1922, xx-313. Edit. Stephen L. Pitcher. Ils. - Barcelona, Sociedad General de Publicaciones, s. f. [1922], 309. Ils.; - (Novela americana). Boston, Heath, 1926, xiv-298. Edit. J. Warshaw. Ils. Lorraine Balmer; -, Barcelona, Sopena, 1932, 253; ibid., 1935. D; ibid., s. f. [1947]. Bibl. de Grandes Novelas; -, Santiago, Ercilla, 1937, 315. Con un estudio de B. Sanín Cano. Te; -, Bogotá, Edit. ABC, 1942, 335 . Vocabulario: 330-335. BPCC, Novela: 7. LC; - (Novela americana). 3 ed. Santiago, Zig-Zag, 1942, III-406. Pref. Armando Bazán. Ils. Boser Bru. Vocabulario: 315-320. Poesías completas: 323-406. Bibl. americana. NC; - (Novela). Buenos Aires, Emecé, 1943, 324. Foto. Vocabulario: 319-324. NC; -, New York, Oxford University Press, 1944, 64. Adapt. y edit. Richard $H$. Olmsted; --, Barcelona, Montaner y Simón, 1944, 343; -, Madrid, M. Aguilar, 1945, 605. Pref. F (ederico) S(áenz de R(obles). Col. Crisol: 90; - (Novela). Buenos Aires, Edit. Castelar, s. f. [¿ 1946 ?], 318; (Novela americana). Buenos Aires-Montevideo, s. 1., s. f., 304. D.

Trad. María (A South American Romance). New York, Harper, 1890, xx-302. Trad. Rollo Ogden. Pról. Thomas A. Janvier. T; ibid, 1900. LAC; ibid., 1918. D LC Te; -, São Paulo, Companhia GráficoEditora Monteiro Lobato, 1925, 231. Trad. Murilo Torres.

"Ha sido traducido al francés, no sabemos con cuánto éxito, por una señora ..." Cortázar, 56.

"En 1880 se ofrecieron en venta ejemplares de una nueva edición, aumentada y corregida. El anuncio ponía en guardia al público lector a propósito de una edición chilena descuidada y no autorizada." Rodrigo Miró, Orígenes de la literatura novelesca en Panamá. Panamá, Imp. Nacional, 1948, 19, nota (4).

Já́n, Jeremías (¿Panamá? 1869-1909)

Mélida. Nueva York, Imp. franco-española de Louis Weiss, 1888, 626.

". . novelón interminable, indefinible e ilegible, de un exotismo suigéneris ... Enmarañada historia de crímenes, tiene por escenario Paris." Rodrigo Miró, Orígenes de la literatura novelesca en Panamá, Panamá, Imp. Nacional, 1948, 21-22. 
Jaramillo, Marco Antonio (Sonsón 1849-1904)

Mercedes. Medellín, Tip. de San Antonio, 1907.

Novela histórica. Tomás Carrasquilla la estimaba como la mejor novela colombiana después de Maria. Ortega, s08.

Jaramillo Angel, Rodolfo

Hombre y destino (Novela). 1942, 142. (Ni lugar ni casa editora). $B N$.

Jaramillo Arango, Rafael

Barrancabermeja (Novela de proxenetas, rufianes, obreros y petroleros). Bogotá, Edit. E. S. B., 1934, 86. LC.

Véase: Latcham, 7-10; Wade, 479.

En prep. El señor alcalde (Novela de la vida bogotana).

Jaramillo Arrechea, Santiago

Calixto (Novela educativa). Cali, Edit. América, 1941, 148. Pról. Gregorio Sánchez Gómez. BN.

“... la primera creación novelística de su autor... Salta, pues, a la vista el discreto propósito educativo que se busca con este libro de estructura nada vulgar." Pról.

Jaramillo Gartán, UVA (seud. Laura D'Avignon) (Tolima 1893- )

Corazón berido (Novela).

"Sentimental y extensa." Ospina, 447.

Maldición (Novela).

"Inédita ... extensa . . trágico-sentimental." Ospina, 447.

El campamento (Novela).

"Corta ... trágico-sentimental." Ospina, 447.

Infierno en el alma (Novela).

"... de costumbres antioqueñas, la preferida entre mis obras [las de la autora], porque estudia y estereotipa la raza." Ospina, 447. 
Jaramillo González, Gutllermo (seud. Pierre Yaromín) (Fredonia $1894-\quad$ )

Redención, en La novela semanal, $\mathrm{x}, 9,22$ de marzo, 1923, 91-101. $\mathrm{BN} \mathrm{Y}$.

Jenny (Véase: Dávila de Ponce de León, Waldina)

JuANCÉ (Véase: Martínez Uribe, Juan Cristóbal)

Karl, Abel (Véase: Mantilla, Daniel)

Lanao Loaiza, Aquiles

Leo Agil (Novela). Santa Marta, Tip. Comercial, s. f. (1934), 185. Pról. Luis Aurelio Vergara (Santa Marta, octubre de 1932). "Palabras liminares": El autor (Santa Marta, octubre de 1934). BPB.

"... estos breves relatos moceriles, ampliamente vividos en un ayer, hoy lejano y de recuerdos..." El autor.

Latino, Srmón (Véase: Pareja, Carlos H.)

Latorre, Gabriel (Medellín 1868-1935)

Kundry. Medellín, Antonio J. Cano, 1905, 178.

"... retratista de la alta sociedad..." OM, Hist., 244.

"... Latorre, enamorado de París y en general de la vida europea, profesa aversión soberana a la tierruca montañesa, y de cuando en cuando la vapula con frases hirientes y desconsoladoras para los que no la conocen." Cortázar, 91-97.

Lemos Guzmán, Antonio

Canto de vida, en La novela semanal, I, 28, 2 de agosto, 1923, 299. 310.

León Rey, José Antonto (Cundinamarca 1903- )

En prep. Tempestad (Novela). 
Londoño González, Hasenneth (Bogotá 1906- )

La casica esmeralda (Novela).

Citada por Ospina, 535 .

Londoño Villegas, Eduardo

El Rey de los Cangrejos.

"Eduardo Londoño Villegas had already established his reputation as a novelist with his El Rey de los Cangrejos." Véase: Handbook of Latin American Studies, 1945, 292.

Lope de Azuero (Véase: Márquez, Tomás)

López, Luis Carlos (Cartagena 1885- - )

María Paz.

Ladrón y L-GP la citan como novela.

López Gómez, Adel (Armenia 1900- )

El niño que vivió su vida, en Repertorio selecto (Bogotá), vi, 58, 17 de diciembre, 1935, 261-293. Pról. Daniel Samper Ortega; -, en Repertorio selecto, 1935, 60. Conceptos. Ils. LC; -, Bogotá, Edit. ABC, 1938, 60; - (Una novela y unos cuentos). Manizales, Imp. Oficial, 1942, 188. Ils. Gonzalo Quintero. El niño que vivió su vida, 5-102; 7 cuentos ocupan las páginas 103-188.

La romántica bistoria de Daniel Saldaña.

"Novela breve." Citada por Ospina, 559.

Anuncia: La ciudad de las luces verdes (Novela).

$$
\text { El vuelo del corazón (Novela). }
$$

En prep. Una mujercita que pasa (Novela).

Dietario de la vida sencilla (Novela).

López de MEsa, LuIs (Antioquia 1884- )

La tragedia de Nilse. Bogotá, Cromos, 1928, 233. LC. 
La biografia de Gloria Etzel. Bogotá, Minerva, 1929, 173. LC.

Véase: Ortega, 739-746.

López Míchelsen, Alfonso

El padre bobemio de un liberalismo burgués. Bogotá, Edit. Santafé, s. f. [e 1935 ?]. Bibl. de los últimos: I.

Biografía novelesca.

\section{López-Penha, Abraham Zacarías (Curazao 1865- . )}

Camila Sánchez (Novela de costumbres). Barcelona, Espasa \& Cía., 1897, 288. Ils. José Cabrinety.

Véase: Max-Thein, "Camila Sánchez," en El repertorio colombiano, Xvir, $1898,334-342$.

La desposada de una sombra (Novela sud-americana). París-México, Vda. de Ch. Bouret, 1903, 204. Bibl. de los novelistas. LC Y.

Una novela de amores bastante original.

En prep. Innominata.

LoRenzana L., MáxIMo

Diego Velasco. Bogotá, “La luz,” 1905, 259. LAC LC Y.

La decadencia moral y física de un joven cundinamarqués de mucha promesa que soñó con lograr grandes cosas en Bogotá.

Lucio, Manuel de Jesús (Cartago 1890- )

Entre dos almas (Edición definitiva). Bogotá, Minerva, 1932, 193.

“. . . es un ensayo analítico de psicología y de costumbres ... dividido en dos partes. En la primera, titulada 'Libia,' describe ... el amor afortunado con una mujer que supo comprenderlo. En la segunda parte, 'Marta,' destaca el mismo otra alma de mujer, indomable $\mathrm{c}$ indomada que coge entre sus manos el corazón del hombre que la ama y lo estruja hasta morir."

Lusignan, Marzia de (Véase: Juanita Sánchez Lafauric) 
Luz, Hernando de la (Yolombó)

Montañas de oro (Novela aldeana), en Montañas de oro (Manizales, Arturo Zapata, 1939, virl-257. Pról. El autor. LC), 37-109.

Carmenza (Novela de costumbres), en Montañas de oro (1939), 121-257.

"En estos cinco estudios ... encontrará el lector el contenido racial de algunos hechos e imágenes de Yolombó, el pueblo donde yo nací..." Pról. a Montañas de oro.

En prep. La oración de la llama (Novela indígena. Tragedia de la sangre nativa que desapareció en brazos de dos arterias, la española y la africana. Motivo de la tierra virgen, cuando el amor era un canto de agonia.)

Madredo, Manuel María (Cartagena 1815-1888)

Nuestro siglo XIX (Cuadros nacionales). Bogotá, Nicolás Pontón, 1868, 447. LAC.

Véase: LA, 228-229. "En novelas y cuadros de costumbres escribió El moján, La maldición-que publicó en El mosaico (1860) - y Nuestro siglo XIX, trazos de la vida neogranadina, en que quiso, con pincel realista, trasladar al papel gran copia de las costumbres de la capital y del río Magdalena, adelantándose en veinte años al jefe del naturalismo francés, pues Madiedo tenía escrita su obra desde 1846, aunque sólo la publicara en $1868 \ldots$. OM, Hist., 127.

Madrid, Romeo (Véase: Nieto, Ricardo)

Malaquita, Carlos (Véase: Carrasquilla, Tomás)

Malayer Cayo, Leónidas

El martirio del amor.

"Novela sentimental." Cat. Libr. Colombiana, 1945.

Mallarino IsaAcs, Manuelita

Las memorias de Marcela. París, "Le Triangle," 1934, 138. LC.

La autora es "la sobrina predilecta de Jorge Isaacs." Escribió el libro en París en 1930. 
Manrigue, Ramón

La venturosa (Novela). Bogotá, Edit. Kelly, 1947, 363. Pról. El autor, 11-17.

"Gesta de guerrilleros y bravoneles, relato de íncubos y súcubos, amores, trasgos y vestiglos." Subtítulo: Novela de costumbres. Episodios de la última guerra civil de 1902. La acción pasa en el Alto Magdalena.

Véase: Boletin del Instituto Caro y Cuervo. III, 1-3, enero-diciembre, 1947,332 .

Mantrilla, Daniel (seud. Abel Karl) (Piedecuesta 1836-1868)

Una tarde de verano. París, C. Thunot y Cía., 1860; -, en Articulos escogidos de Abel Karl (Bogotá, Echeverría hnos., 1879, 211.)

Publicada antes en un periódico de Bogotá.- Véase: LA, 236.

Resignación. París; -, en Artículos escogidos de Abel Karl (1879).

Márquez, Tomás (seud. Lope de Azuero) (Medellín 1890-1939)

Impresiones de Jaime Kéndel (Novela). Manizales, Arturo Zapata, 1934, 168. LC.

La vieja historia de la mujer despreciada; y del hombre, al principio amado, después odiado.

"Muchas poesías, cuentos, novelas cortas, etc. conserva inéditos ...donde Márquez mostró más erudición fué en las críticas firmadas Lope de Azuero. Bajo este nombre figuraron dos individuos y uno de ellos fué Márquez...” Ospina, 643.

Marroquín, José Manuel (seud. Gonzalo González de la Gonzalera; P.

P. de P.; Pero Pérez de Perales) (Bogotá 1827-1908)

Blas Gil. Bogotá, J. J. Pérez, 1896, vir-432. Y; ibid., 1897. BN LAC Y.

“.. novela biográfica ... inspirada, aunque remotamente, en las picarescas españolas..." Cortázar, 26-27.

El moro. New York, Appleton, 1897, 298. Pról. J. G. P. Ils. LC; ibid., 1904; - 2 ed. Bogotá, Arboleda y Valencia, 1921, xx-341. Pról. José Manuel Marroquín Osorio, Presbitero. Ils. Lit. Col. 3. LAC Y; 
- 3 ed. Bogotá, Edit. ABC, 1937, 384. Ils. "Algunos conceptos": 3-4. D LC; - 4 ed. (Edición conmemorativa de la Fundación de Bogotá). Bogotá, Ministerio de Educación Nacional, 1938, 169. Ils. Enrique Gómez Campragano. LC NC; - (Autobiografía de un caballo). Buenos Aires, Edit. Colombia, 1943, 280. Pról. Roberto Arrazola. "Polémica": R. A. T'exto el de Bogotá de 1938. BN.

"Es un libro precioso, que aun cuando tenga antecedentes en otras literaturas (Cadichón, Azabache, etc.), tiene olor y color de nuestras sabanas andinas $y$ es de las producciones originales de nuestra literatura. Se revela. allí la observación del hombre que conoce el campo, no como excursionista, sino como señor y propietario, y a quien el caballo inspira cariño de compañero y casi de amigo. Azabache es figura demasiado seria y formalota para el gusto latino. El héroe de El moro tiene más gracia, más ingenio, y con sus lances y aventuras conquista la atención del lector, a quien hechiza, además, el primor y la pulcritud con que está escrito el libro." Gómez Restrepo.

Véase: Cortázar, 27-29; Carlos García-Prada, Estudios bispanoamericanos (México, s. f.), 285-297; C. Martínez Silva en El repertorio colombiano, xv, 1897, 81-96; Wade, 476.

Entre primos, en Revista nacional (Bogotá), mayo-agosto, 1897; -, Bogotá, Eduardo Espinosa Guzmán, 1897, 404. BN LAC Y.

"Los médicos declaran que el mal de Cecilia es un caso de lepra ... Se frustra el matrimonio con Pablo, pero es tanto el amor de Cecilia para ćl. que antes de bajar a la tumba quiere ser su esposa ... logra incorporarse en el lecho y... se desposa con Pablo y con la muerte." Cortázar, 22-25.

Amores y leyes. Bogotá, G. R. Calderón, 1898, 304. I.AC Y.

Novela de Bogotá de la segunda mitad del siglo pasado. "La lucha con la adversidad después de haber gozado de relativa opulencia, lucha personificada en la infeliz pareja, y el triunfo de la justicia, son los fines de la novela." Cortázar, 19-22.

Marroquín, Lorenzo (Bogotá 1856-1918)

Pax (Novela de costumbres latinoamericanas). Bogotá, "La luz," 1907, xvi-643. "Carta:" L. M. LAC; - 2 ed. Bogotá, "La luz," 1907 , xivi-X-475. Pról. Miguel Navía y Guillermo Camacho. "Carta": L. M. D; ibid., 1927; - 3 ed. París, Paul Ollendorff, s. f. [1910], 497. C Gh IAC Y. 
En una "Carta," dirigida a José María Rivas Groot y fechada el 31 de marzo de 1907, el autor dice lo siguiente: "El 17 de septiembre de 1906 le comuniqué haber terminado, rehecho y enviado a la imprenta la novela principiada en colaboración con usted hace tiempos y que había quedado inconclusa y en estado embrionario."

Trad. Pax. New Y'ork, Brentano's, s. f. [1920], virI-480. Trad. Isaac Goldberg y V. W. Schierbrand. Pról. Isaac Goldberg. C NC T.

Véase: Cortázar, 103-111; OM, Hist., 241-424; y Wade, 477.

Martillo, Don Juan del (Véase: Botero Guerra, Camilo)

Martínez Clark, Julio G.

De castellana estirpe. 1933.

"Novela histórica." Cat. Libr. Colombiana, 1945.

\section{Martínez Orozco, Alfredo (Cali)}

La voz de la tierra (Novela). Cali, Edit. América, 1932, 332. Mapa. BPB; -2 ed. Bucaramanga, "La cabaña," 1936, 338. BSM LC. 3 ed. México, Edit. Stylo, 1950, 310.

Véase: Carlos García-Prada, Books abroad, vin, 4, 1933, 430.

"Intenso relato de la selva ... por tipos vigorosos que hablan castellano y prosiguen la epopeya ... de abrir tierras nuevas a la especie humana... [en las] montañas de Chilí, territorio baldío, extendido al oriente de la gran cordillera central ... tibias márgenes del río Cucuana, no lejos de las llanuras del Tolima." José Vasconcelos, La antorcha (Citado por la casa editora.)

Yajángala (Novela). México, Edit. Stylo, 1950, 168. Introducción por el autor. Una leyenda de los indios poeces de la región del Cauca. En prep. La arteria.

Martínez Uribe, Juan Cristóbal (seud. Juancé) (Girón 1896- )

Margarita Ramírez tuvo un bijo (Novela). Bucaramanga, Imp. del Departamento, 1938, 196. LC.

Aunque tiene una trama novelística rudimentaria, es, más que una novela, una serie de breves disquisiciones literarias y artísticas y una co- 
lección de anécdotas de la vida de Bogotá y Bucaramanga allá por el año de 1915.

Quince minutos de intermedio (Novela).

Ultimo pecado (Novela).

Citadas por Ospina, 680.

Martínez Zaldúa, Ramón

Los asteroides (Novelas cortas). Bogotá, Minerva, 1927, 235. Pról. El autor.

"... estas [12] novelas cortas de motivos psicológicos... algunos de sus temas los recogí en mis viajes por otros países..." Pról.

Tras el nuevo Dorado (Novela). Barranquilla, Edit. Mundial, 1928, 230. BPB.

Mateus, Jorge (Chiquinquirá 1880-1935)

La raza expiatoria, en La novela semanal, 1, 22, 21 de junio, 1923, 231-242. BN Y.

De la romeria, en La novela semanal, I, 1923.

La que a nadie queria, en La novela semanal, 1923.

El extranjero (Novela americana). Bucaramanga, "Ia cabaña," 1928 , 209. Pról. El autor. Foto. IC.

Una novela bastante fantástica de intriga en las minas de esmeraldas y en los círculos financieros de la capital.

Anuncia: Aves de rapiña (Novela bogotana).

En prep. La bora fatal (Novela).

Mejía, Etrfanio (seud. Emilio) (Yarumal 1838-1913)

Amelia.

"Narración novelesca." Ospina, 720. 
Mejía Angel, Carlos (seud. Ciro Mendía) (Caldas 1892- )

Rosenda, en La pluma semanal, junio de 1923.

". . novela realista..."

Mejía Robledo, Alfonso (Caldas 1897- )

Rosas de Francia (Novela colombiana). 1 ed. París, Edit. FrancoIbero-Americana, 1926, 256. LC NC Y; -2 ed. Pereira, Edit. Panoramas, 1938.

Novela premiada en 1922 en el Concurso de Autores Americanos abierto por la Editorial Franco-Ibero-Americana.

"... traducida al francés." Ospina, 733.

La risa de la fuente (Novela inédita). 1 ed. Barcelona, Cervantes, 1930 (abril), IX-274. Pról. Vicente Clavel. Bibl. de novelistas hispanoamericanos: 1. LC; -2 ed. 1930 (julio).

Novela escrita entre julio y septiembre de 1923 . ". . traducida al inglés." Ospina, 733. No se pudo comprobar el dato.

Para publicarse: ¡Hacia América! (Novela).

Huracánt (Novela).

Bajo el silencio.

"Tiene para publicarse varias novelas y poesías con el título de Bajo el silencio." Ospina, 734.

Mejía Vallejo, Manuel (Medellín 1923- )

La tierra éramos nosotros (Novela). Medellín, Balmore Alvarez G., 1945, 229. BSM.

Novela regional basada en leyendas y tradiciones antioqueñas.

Méndez de Mendoza, Mendo (Véase: Guzmán, Diego Rafacl de)

Mendía, Crro (Véase: Mejía Angel, Carlos)

Mendoza de Vives, María

El altha de una madre. Bogotá, 1873.

Véase: Ladrón, 360. 
Mercado, ANDRÉs (Riosucio 1886- )

Para publicarse: Holocausto (Novela).

Citada por Ospina, 756.

Mesa y Posada, Samufi Arturo (Medellin 1894- )

De la carioquinesis a la necrosis (Novela médica).

Citada por Ospina, 773 .

Mina, Juan de la (Véase: Samper, José María)

Molina, Felipe Antonio

Muros de la ciudad (Novela de un medio ambiente). Bogotá, Edit. Santafé, 1935, 332. Bibl. de los úlcimos: 2. LC NC.

"... novela descriptiva del ambiente y de la psicología de su rincón. nativo (Ocaña)." OM, Hist., 283.

En prep. Asfalia (Novela de un taxi).

Molina, Juan Josté (Medellin 1838-1902)

Los entreactos de Lacía, en Ensayos de literatura y de moral (1 serie. Medellín, Imp. Republicana, 1886, vi1-394), 24-43.

El final de un proceso, en Ensayos do literatura y de moral (1886), $133-154$.

Montoya T., Wenceslao (Ántioquia 1889- )

Orgullo y amor (Novela colombiana). París, Edit. Franco-IberoAmericana, s. f. [? 1923 ?], 382. LAC.

Novela de la vida parroquial, fiel hasta en el lenguaje, que termina. así: "Y las Rodríguez continúan frecuentando cada vez más el templo y dedicadas totalmente a obras de piedad, sin que por esto dejen de destrozar sin descanso las ajenas reputaciones ni de acortarle a la falda algunos centímetros cada año."

Del remolino (Novela corta), en La novela semanal, (Bogotá), [i 1923 ?]; -, en El colombiano (Medellín).

Citada por Ospina, 815. 
La fiera (Novela). Medellin, Tip. Industrial, 1927, vi-311. Pról. Pedro P. Betancourt, Foto. LC.

Novela premiada por la Academia Nacional de la Lengua.

"... una novela tendenciosa, porque esa Fiera... es la aberración política ... La pintura de la vida parroquial no puede hacerse con mayor fidelidad... antes, cuando las revoluciones se sucedían en serie que parecía interminable, el cuadro que ha recogido el novelista se veía en todos suestros pueblos..." Pról.

Diamante negro (Novela corta).

Citada por Ospina, 815 .

Montserrate, Isabex de (Véase: Pinzón Castillo de Carreño-Mallarino, Isabel)

\section{Morales Pino, Augusto}

Los de en medio. Pasto, Imp. del Departamento, 1938, 154. LC NC.

Novela de la vida urbana. "... Parece increíble... Hemos debido empezar por poner en práctica, en nuestra vida intima, las ideas que expresábamos. Tal vez vengan otras generaciones... Nosotros fuimos sólo unos cerebrales."

Morales Pradilla, Próspero (Tunja 1920 - )

Perucbo. Bogotá, Libr. Colombiana, 1945, 179. Pról. Agustín Morales Vargas. BN BPB.

"... los recuerdos sentimentales de un repórter bogotano y la descripción realista de su mundo mezclado de ambiciones, humor, ideal y bohemia." Cat. Libr. Colombiana, 1945.

Motta Salas, Julián (Neiva 1891- )

Alonso Quijano el bueno (Don Quijote en Villaseñor). Bogotá, 1930, 300. Pról. El autor, 7-13. LC.

"Tarea delicada la de hacer que salga otra vez a buscar las aventuras por esos mundos el ingenioso hidalgo Don Quijote de la Mancha ... no laa salido a plaza con manías de imitación, ni con ánimo de agraviar la memoria del rey de los escritores de Castilla. Muy al icontrario, estas líneas son un himno de cariño y de veneración..." Pról. 
Mũ̃oz, Luis J., S. J. (Guatemala 1858-1927)

El doctor Pescaderas (Novela de costumbres). Medellín, Libr. Bedout, 1909, 232. Pról. El autor. BPC BSM.

Novela escrita en 1897 y destinada para una revista religiosa que suspendió la publicación.

Véase: Ladrón, 389-390.

Navarro, Nepomuceno J. (San Gil 1834-1890)

El gamonal (Novela de costumbres). Bogotá, s. f.; -, en Flores del campo (Colección de producciones literarias. Socorro, Imp. del Estado, 1871, XIII-342. "Al lector": J. M. Lombana. "A la soledad": J. David Guarín; "Juicios críticos": J. David Guarin; "Flores del campo": de El bogar. $\mathrm{BN}), 1-56$.

El camarada. Bogotá, 1866; -, en Flores del campo (1871), 165216.

El zapatero (Novela histórica). Bogotá, s. f.; -, en Flores del campo (1871), 243-280.

La estrella del destino (Episodio de la colonización de Sur-América). Bogotá, s. f.; -, en Flores del campo (1871), 283-320.

"El gamonal, El camarada y El zapatero son novelas cortas en las que ayudado de una pequeña trama presenta en relieve los defectos de nuestras mal practicadas instituciones, los hábitos de los pueblos y grandes ciudades ... como narrador y descriptor es verdadero, exacto, fiel y correcto ... No queriendo el autor adulterar el suceso histórico para sujetarlo a las exigencias de una novela (La estrella del destino), coordinó en forma de leyenda ... el descubrimiento del Pacífico por . . . Balboa." Guarín.

Yéase: LA, 263, quien clasifica La estrella del destino como novela.

Neira Acevedo, José Ignacio

El sereno de Bogotá (Novela histórica). Bogotá, "La nación," 1867, 67 ; - Barcelona, Lloréns hnos., s. f. [e 187 ?], 135. LAC Y; 一, Barcelona; Juan Tarrall y Cía,, 1890, 64. LAC.

Véase: LA, 264-265. 
NTETo, JUAN José (Cartagena 1804-1866)

Yngermina, o La bija de Calamar (Novela histórica, o Recuerdos de la conquista, 1533-1537). Kingston, Jamaica, Rafael J. de Córdoba, 1844, 2 v. xrx-93-109. Breve noticia de los usos, costumbres, y religión del pueblo de Calamar: $\mathrm{V}$-xrx. BN Y.

Los moriscos. Kingston, Jamaica, Rafael J. de Córdoba, 1845, 119.

ElCastillade Chogres, en La democracia (Cartagena), 1850-1852 (?).

Véase: OM, Hist., 226.

Nireto, Pablo E.

La reina del mar. Faltan lugar, casa y fecha de publicación. 368 páginas. LAC.

Nieto, Ricardo (seud. Romeo Madrid; Juan Servien) (Guacari 1878 - )

Diario de Pedro (Novela).

Citada por Ospina, 93.

Nigreros, Josí (Véase: Ortiz, José Joaquín)

Noguera Corredor, V.

Infierno azul o El país de los toxicómanos. Bogotá, Edic. Santafó, 1939, 332. LC.

Véase: Wade, 481.

Núñez de Prado, G.

Un idilio en el Cauca (1810-1814). Barcelona, "Gallach," s. f. 325. Bibl. de episodios americanos. LAC.

Oreso, Candelario (seud. Publio Chapelet) (Mompós 1849-1884)

Las cosas del mundo (Novelas semi-históricas), po: Publio Chapelet. La familia Pygmalión. 1 Serie. Bogotá, Medardo Rivas, 1871, 19. 
Ocampo de Sánchez, Natalia

Una mujer (Novela histórico-social). Manizales, Arturo Zapata, 1936, xn-198. Pról. El autor. LC.

Orga (Véase: Acosta de Samper, Soledad)

Ortiz, José Jonquír (seud. José Nigreros) (Tunja 1814-1892)

María Dolores, o la historia de mi casamiento (Novela original), en El cóndor (Bogotá), 1841; - (Novela), Bogotá, Libr. Nueva, 1895, Bibl. popular: 15; ibid., 1917, 39. Y.

Escrita en Anapoima en 1836. "... es una especie de cuento o relato... que no tiene otros atavíos que los de un cuadro de costumbres sencillamente narrada ... La sinceridad con que está descrita ... demuestra que los hechos... son verdaderos, aun puede colegirse que el protagonista es el mismo autor, y que aquella historia de un matrimonio feliz bien puede ser su propia historia." LA, 285-286.

Huérfanas de madre (Novela corta), en La caridad (Bogotá).

Citada por Cortázar, "Apéndice."

Ortiz, Juan Francisco (Bogotá 1808-1875)

El oidor de Santa Fe, en El dia (Bogotá), números 261-263, 1845; --, en Cuadros de costumbres, Bogotá, F. García Rico, 1878, 398. Edit. José Joaquín Borda.

Descripciones locales de Colombia. "Narración anónima novelada" atribuida a Juan Francisco Ortiz por OM, Hist., 225.

Carolina la bella, en La guirnalda (Bogotá) (¿ 1855 ?); -, Bogotá, Libr. Nueva, s. f. [i 1899 ?], Bibl. popular: 134. LAC; - 3 ed. Bogotá, s. f. [eं 189 ?], 107-140. Y.

Novela corta epistolar, cuyo tema es la censura del duelo. Véase: LA, 288-289.

Ortiz, Melitón y Gooding, G.

Los dos amigos (Novela de costumbres). Bogotá, Nicolás Pontón, $1873,63$. 
ORTIZ, RAFAEL (Bogotá 1844-?)

Edwvigis (Novela de costumbres). Bogotá, Zalamea hnos., 1889, vI113. Pról. G. Acevedo. Y.

Véase: LA, 290-291.

Para publicarse: La semilla del clavel. (Cortázar, "Apéndice.”)

Osoruo, Lưs EnRIQue (Bogotá 1896- )

Primer amor (Novela de actualidad). Bogotá, Régulo Domínguez, 1915, 171, Pról. El autor. LAC Y. Pról.

"... ensayo estudiantil ... escrito a la edad de 17 años .. 1913."

Lo que brilla (Novela). Bogotá, Juan Casís, 1917, 119. LAC LC Y.

Una novelita de amores.

Los que jugaban al amor (Novela corta). Buenos Aires, 1922; -, en La novela semanal, 1, 27, 26 de julio, 1923, 283-298.

El cementerio de los vivos, en La novela semanal, I, 6, 1 de marzo, $1923,55-67$. BN Y. BN Y.

Malos ojos, en La novela'semanal, $1,8,15$ de marzo, 1923, 79-89.

El beso del muerto, en La novela semanal, 1, 11, 5 de abril, 1923, 113-121.

Novelita dialogada.

Sueños fugaces, en La novela semanal, I, 20, 7 de junio, 1923, 207219. BN Y.

"Novelas cortas: las que aparecen en La novela semanal y Pictorial review." Ospina, 165 .

"Luis Enrique Osorio (1895), fundador de La novela semanal, y autor de muchos cuentos, novelas y ensayos diversos..." Ortega, 1063.

Osorio Lizarazo, José Antonio (Bogotá 1900- )

La casa de vecindad (Novela). Bogotá, Minerva, s. f. [c 1930 ?], 255. LC. 
Véase: Charles N. Staubach, "The Novels of J. A. Antonio Lizarazo," Hispania, xxix, 2, mayo de 1949, 174.

Barranquilla-2132 (Novela). Barranquilla, Tip. Delgado, 1932, 177. LC NC.

"Ahora Juan Francisco Rogers, sepultado en una extraordinaria suspensión de las facultades vitales entre los cimientos de un edificio de Barranquilla en el año 1938, y descubierto, para cornar a la vida, en el año 2132 , sufría la sensación de su propia inutilidad . . Cada momento descubría nuevas interpretaciones erradas de la vida, nuevas manifestaciones contradictorias de la civilización ... El mundo se había deformado estúpidamente."

La cosecha. Manizales, Arturo Zapata, 1935, 285. LC NC.

Véase: Wade, 479.

El criminal (Novela). Bogotá, "Renacimiento," 1935, 308. BN LC.

"Novela de los procesos físicos y psíquicos de la sífilis." Cat. Libr. Colombiana, 1945. Véase: Staubach, obra citada.

$J o b$, en SSO: 17, 83-109.

Hombres sin presente (Novela de empleados públicos). Bogotá, Minerva, 1938, 283. BN LC.

Una novela realista y pesimista de los empleados públicos. Véase: Staubach, obra citada.

Garabato (Novela). Santiago de Chile, Ercilla, 1939, 280. LC.

Véase: Staubach, obra citada.

El bombre bajo la tierra. Bogotá, Prensas de la Bibl. Nacional, 1944, 327. BPCC, Novela: 8. BN LC.

En 1942 obtuvo el premio único en novela, en el segundo concurso literario latinoamericano patrocinado por la editorial Farrar y Rinehart.

Véase: Staubach, obra citada. Véase: Latcham, 27-31, para una crítica de cada una de las novelas arriba citadas.

Fuera de la ley (Historias de bandidos). Bogotá, Edit. Mundo al día, s. f. [c 1945 ?], 157. BN.

Contiene las siguientes novelas cortas: José del Carmen Tejeiro, 5 106, y Antonio Jesús Ariza, 107-157. 
Para publicarse: Tiempo muerto (Novela).

En prep. Los bárbaros (Novela).

P. P. DE P. (Véase: Marroquín, José Manuel)

Pacheco, Gabriel A.

Maldita sea la guerra (Novela). Barranquilla, 1942.

Véase: Cat. Libr. Colombiana, 1945.

Javentud y vicio. Barranquilla, Licografía Barranquilla, s. f. [1944], 157. Pról. El autor. BN.

Un mejicano en el frente condenado después de la guerra. Barranqui1la, Empresa Litográfica, 1946, 208. Pról. El autor. LC.

Palacios, Eustaquio (Roldanillo 1830-1898)

El alférez real (Novela-Crónicas de Cali en el siglo yvmr). Cali, Imp. del autor, 1886, II-268. Y; - 2 ed. Palmira, Imp. Popular, 1903, Ir200. Dedicatoria: El autor. Foto. LAC Y; - 3 ed. Cali, Carvajal y Cía., 1923, 234. Dedicatoria: El autor (fechada: Cali, 16 de octubre de 1886). Foro D; -, New York, Oxford University Press, 1941, xvin-205. Edit. John L. Martin. Ils. LC; -, Bogotá, Prensas de la Bibl. Nacional, 1942, x-353. Pról. Enrique Uribe White. BPCC, Novela: 2. LC; Bogotá, Edit. Kelly, 1943, 321. Pról. Enrique Uribe White. Dedicatoria. BPCC, Novela: 2.

"... cuento puramente fantástico para describir personajes reales y hechos verdaderos y las costumbres de esta ciudad (Cali) ..." a fines del siglo xvir. Cortázar, 53-54.

Véase también: Antonio Gómez Restrepo, Santafe y Bogotá, II, 293-300. Ils.

Pardo Fareuo, Enrique (seud. Luis Tablanca) (Santander 1883- )

Tierra encantada. Bogotá, Juan Casís, 1926, 236. Pról. El autor; 2 ed. Bogotá, Edit. Santafe, 1927, 226. Pról. El autor. LC.

". . es en cierto modo un canto amoroso a la ciudad [Ocaña] donde pasé buena parte de mi juventud; una evocación de lo que era hasta unos años esa urbe melancólica y soñolienta..." Pról. 
Una derrota sin batalla (Novela). Bucaramanga, "La cabaña," 1935 , 311. Pról. El autor. BN LC.

"... extraje dichos elementos de la cantera libre de la vida, en que observar es coger con derecho a utilizarlas cuantas cosas la forman, unos paisajes y unos pueblos y las figuras humanas que en ellos se mueven..." Pról.

Véase: L. F. Nieto Caballero, Atenea (Chile), xxxrv, 132, junio de 1936, 411-414; Wade, 480 .

En prep. La mujer que se cortó el moño (Novela).

Pareja, Carlos H. (seud. Simón Latino) (Cartagena 1900- )

Sacrificios, en La novela semanal, $x, 16,10$ de mayo, 1923, 165-172. BN Y.

Antioquia para los antioqueños (Novela). Medellín, Imp. Helios, 1923.

Paulrna (Véase: Herrera de Núñez, Priscila)

Perdomo Rivera, Saúl

Amor incierto.

"Novela romántica ..." Cat. Libr. Colombiana, 1945.

Pereira, José Francisco (Cartago 1789-1863)

La lanza del célebre pijao don Baltasar.

"Escribió la novela La lanza del célebre pijao don Baltasar que publicó Nariño en 1815." Ospina, 269.

Pereira Gamba, Próspero (Bogotá 1830-1896)

Amores de estudiante (Novela de costumbres nacionales, sacada de un precioso manuscrito neivano). Bogotá, Echeverría hnos., 1865, 132. BN.

Escrita en 1858 . Véase: Ladrón, 434. 
Pírez, Felmie (Soconsuca 1836-1891)

Huayna Cápac (Novela original). Bogotá, Echeverría hnos., 1856, 112. Pról. El autor. D LAC Y.

"... me atrevo a dar a la prensa la serie de novelas históricas que de algún tiempo atrás tengo escritas, i que pueden reputarse como un bosquejo de las últimas décadas del imperio de los Incas ... Mi colección de novelas indianas, ya que V. [Amigo Alpha] lo quiere, será lo que nutra el folletín de El tiempo por algunas semanas." Pról.

"... le fué necesario consultar el idioma, la estructura de la sociedad, costumbres y monumentos antiguos y empaparse en la crítica juiciosa del célebre Prescott." Cortázar, 36-40.

D. LAC.

Atabualpa (Novela original). Bogotá, Echeverría hnos., 1856, 143.

Los Pizarros (Novela original). Bogotá, Echeverría hnos., 1857, 556. Foto. D LAC LC Y.

"Continuación de Atabualpa."

Jilma, o contimuación de los Pizarros (Novela original). Bogotá, Ovalles i Cía., 1858, 211. Y.

Véase: Ladrón, 437-438.

El caballero de la barba negra (Novela original). Bogotá, Ovalles i Cia., $1858,57$.

Los jigantes (Novela original). Bogotá, Imp. de Gaitán, 1875, 354. Bibl. del "Diario de Cundinamarca." BN LAC LC Y.

‘. . abarca el gran cuadro histórico que precedió a la Independencia de Colombia y Venezuela ... tiene personajes históricos muy bien caracterizados... Para el curioso, amigo de rastrear las costumbres de los indios de nuestras selvas bravías ... es fuente de investigación... Otra de las cosas que describe, y con bastante propiedad, es la vida física e histórica de los llanos..." Cortázar, 31-36.

20 de julio de 1810 (Capítulos de una novela). Socorro, Imp. del Estado, 1878, 50. LAC.

"Edición oficial." "Toda novela tiene algo de historia, toda historia tiene algo de novela." 
Carlota Corday (Novela original). Bogotá, Colunje y Vallarino, 1881,174 . Y. LAC.

Imina (Novela original). Bogotá, Colunje y Vallarino, 1881, 415.

Véase: Ladrón, 437.

Sara (Novela original). Bogotá, Echeverría hnos., 1883, vII-249. LAC Y.

Véase: Ladrón, 437.

El caballero de Rauzán (Novela original). Bogotá, Echeverría hnos., $1887,416$.

Samuel Beli-Beth, el judio. Bogotá, C. Echeverría G., 1888, 115. Y.

Contiene: El bosquecillo de álamos.

Estela. Bogotá, Libr. Nueva, s. f. [cं 1899 ?]. Bibl. popular: 126-129. $\mathrm{BN}$; ibid., s. f. [¿ 191 ?], 167-307. Y.

Publicada en El relator (Bogotá). Cortázar, "Apéndice."

El bosquecillo de álamos. (Véase: Samuel Beli-Beth, el judío, 1888, arriba citada).

Los dos Juanes. (Véase: Enrique Pérez, Vida de Felipe Pérez, Bogotá, "La luz," 1911, 16-17).

Isabel. (Véase: Enrique Pérez, Vida de Felipe Pérez, 16-17).

La muerte del gato. (Véase: Enrique Pérez, Vida de Felipe Pérez, 16-17).

Los pecados sociales. (Véase: Enrique Pérez, Vida de Felipe Pérez, 16-17).

"Publicada en el folletín de su periódico El relator." Cortázar, "Apéndice."

El profesor de Gotinga. (Véase: Enrique Pérez, Vida de Felipe Pérez, 16-17).

La tumba milagrosa. (Véase: Enrique Pérez, Vida de Felipe Pérez, 16-17). 
Tupac Amaru. (Véase: Enrique Pérez, Vida de Felipe Pérez, 16-17).

Véase: Ladrón, 436-437.

"Bien se nota en las novelas de don Felipe la influencia de Alejandro Dumas." Ortega, 270.

El biógrafo de Pérez, Enrique Pérez (Vida de Felipe Pérez, Bogotá, "La luz," 1911), menciona otra novela histórica intitulada Tupac Amaru (7). "Vulgarizó la historia en la novela, y en Los gigantes pintó el géncsis de la lucha magna de nuestra independencia... Sus novelas Estela, Imina, Sara, El caballero de la barba negra, La tumba milagrosa, El caballero de Rauzán, La muerte del gato, Los dos Juanes, El profesor de Gotinga, Isabel, Carlota Corday, Samuel Beli-Beth, El bosquecillo de álamos, Los pecados sociales, agotaron en breve sus ediciones y son poco conocidas de la presente generación." (16-17).

Pérez, T. Alejandro (Sogamoso)

Julia (Novela). Sogamoso, Horacio Isaza C., 1889, 89. Pról. Temístocles Avella M.

"... este primer ensayo ... de nuestro joven paisano..." Pról.

Pérez de Perales, Pero (Véase: Marroquín, José Manuel)

Pérez de Pulgar, Hernán (Véase: Silvestre, Luis Segundo de)

Pineda Castillo, Roberto (Bogotá 1911- )

Panorama de cuatro vidas (Novela). Manizales, Arturo Zapata, 1934, virr-334. Pról. Jorge Padilla. LC.

"... este novelista en agraz se preocupó desde un principio por el trazado de las vidas vulgares, por el andar interno de las emociones en el hombre medio de su vieja ciudad de Santa Fe..." Pról.

Mucbedumbre (Relato pre-novelesco). Santiago de Chile, Ercilla, 1942, 115. LC; -, Bogotá, 1944.

El autor busca un protagonista para su novela que está todavía por escribir. No lo encuentra, y su "pre-novela" consiste en opiniones sobre varias cosas. 
Pinzón Castrillo de Carreño-Mallaarino, Isabel (seud. Isabel de Montserrate)

Hados (Novela). San Francisco, California, Edit. Hispano-América; 1929, 427. Foto. LC.

Dedicada a los Rockefeller, fundadores de la International House de la ciudad de New York.

En prep. Los celos de Maruja.

Pizarro, Alejandro (seud. A pemanto) (Cali 1852-1896)

Hasta su altura (Novela corta), en Revista literaria (Bogotá), I, $1890,230-240$.

Citada por Ospina, 315 .

Pla, Constantino (Véase: Arias Suárez, Eduardo)

Plaza, José Antonio de (180?-1854)

El oidor, en El día (Bogotá), 1848; - (Romance del siglo xvi), Bogotá, Imp. del Neo-Granadino, 1850, 120.

“... novela histórica ... en la cual ... relata los encendidos amores del funcionario español Cortés de Mesa con la bella dama doña María de Ocando ..." OM, Hist., 228.

Posada, Carlos (Cartagena 1845-1887)

Cura, médico y alcalde (Novela).

"Comenzó a publicar en La idea, periódico que con varios amigos fundó en Cartagena, una novela de costumbres titulada Cara, médico $y$ alcalde." Ospina, 337.

"... dejó ... unas novelas inéditas ..." Ortega, 503 .

Posada, Eduardo (Medellín 1862-1942)

El Dorado. Bogotá, Minerva, 1936, 161. Pról. SSO: 36. BN LC T Y.

Trad. L'bomme doré. Liège, G. Thone, 1925, III-119. Trad. Joseph de Brettes. LC. 
"La evocación que hace Posada de El Dorado llamó la atención en Francia, por analogía con la célebre novela (Salambó) de Flaubert, y que traducida al francés, circuló profusamente." Pról.

Natalia (Novela).

"Es autor de ... Natalia, novela ..." Ortega, 1021.

Price, Jorge W. (1853-?)

Emma Perry (Novela católica). Bogotá, "La luz," 1907, xv-312. "Conceptos": José Eusebio Díaz, C. Cortés Lee, Marco Fidel Suárez, Miguel Abadía Méndez, Francisco J. Montoya Lorenzana, José Joaquín Casas. LAC.

Véase: Ladrón, 462.

El diamante rojo. Bogotá, "La cruzada," 1919, 219.

Puerta G., Bernardo (Titiribi 1891 - )

Alma de bidalgos (Novela corta).

"... galardonada ... con mención honorífica en los Juegos Florales de 1925 , promovidos por la Sociedad de Mejoras Públicas de Medellín ..." Ospina, 346.

Sobre el farallón andino (Novela corta).

Citada por Ospina, 346.

Entre el bonor y la muerte (Novela corta).

"Ultimamente Puerta ha triunfado en un concurso internacional de literatura promovido por la revista Tierra nativa de Bucaramanga con su novela corta intitulada Entre el honor y la muerte." Ospina, 347.

QUTJANo, JosÉ

A Londres directamente (Novela colombiana). Medellín, Tip. Bedout, 1931, 402. Pról. 7-11. Ils. LC.

Los amores de Elvira y Ordóñez, desarrollados durante un viaje por al río Magdalena y a Nueva York (no a Londres). 
Rafiavánez, Rodrigo de (Véase: Bayona Posada, Daniel y Gómez Corena, Pedro)

RAMúrez G., Enrique

Las contras (Novela histórica), en Tropical (Ibagué), 1907. BN. Incompleta.

Ramírez Moreno, Augusto (Medellín 1900- )

Los leopardos (Los personajes). Bogotá, Edit. Santafé, 1935, 230. Bibl. de los penúltimos: 7. LC NC T.

Novela histórico-política y autobiográfica sobre el origen de un grupo de escritores jóvenes llamados los "Leopardos." Véase: Ortega, 1178-1185.

Anuncia: Los leopardos (La acción).

Renato (Véase: Acosta de Samper, Soledad)

Rendón, Francisco de Paula (seud. Jaime Valmar; Modesto Acks) (Santo Domingo 1855-1917)

Inocencia. Medellín, Libr. Restrepo, 1904, xrv-175. Pról. Carlos E. Restrepo. LAC LC Y; -, Bogotá, Minerva, 1935, 179. Pról. Hortensia Ceballos de Moreno. SSO: 13. BN LC T Y.

Contiene: Inocencia, 1-97, y Lenguas y corazones, 101-179.

". . supiste explotar dos veneros que son inagotables para el arte: e. corazón humano, que es uno en todas partes; y los materiales aborígenes, que son los que has podido conocer y trabajar mejor; con ellos has hccho la obra más franca, más atrevidamente antioqueña que conozco." Pról.

"... se recuerda sin querer a Pereda, y por lo menos respira uno aires de campo y de una tierra real y efectiva, sintiéndose muy lejos de los artificios bulevarderos $\mathrm{y}$ de las tierras de ninguna parte puramente fantásticas. Aquello sabe a tierra, sabe a lugar, sabe a tiempo y sabe a humanidad." Unamuno, citada por Cortázar, 86-91.

Lenguas y corazones, en Inocencia (1935), 101-179. 
Sol (Novela).

Véase: Ortega, 357-360.

Rengifo, Francisco María (Buga 1870- )

Eufrosina de Alejandria (Novela de reconstrucción histórica de costumbres). $2 \mathrm{v}$.

Citada por Ortega, 977.

Restrepo, José

Dinero para los peces (Novela). Bogotá, Edit. ABC, 1945, 231. BN.

Contiene: Dinero para los peces, 9-144; Un dia de consulado (relato), 147-190; Mi amigo Sabas Pocabontas (relato), 193-231.

Restrepo, LISANDRo (Antioquia 1849-1927)

De paso (Novela), en Memorias intimas de Ramón Pérez.

Citada por Ospina, 436.

Restrepo Jaramillo, José (Jericó 1896-1945)

Roque, en Cuentos (Bogotá, Ed. Colombia 1925, 162), 69-97.

Su primera novela, clasificada como "novelín."

La novela de los tres.

Novela "en que aparecen los complejos humanos vistos a la luz del psicoanálisis." AF, 88.

Otras vidas, en "Lectura breve" de Sábado (Medellín).

David, bijo de Palestina (Novela). Medellín, Libr. Pérez, s. f. 252.

“... un análisis espectroscópico de la raza antioqueña, en su excitabilidad, su presunto judaísmo que el novelista acepta sin rodeos, y su carácter impulsivo." AF, 89.

Véase: Latcham, 19-21, con referencia a Roque, La novela de los tres, y David, bijo de Palestina. 
Para publicarse: Espejo de feria (Fantasía), en la BPCC.

En prep. Gilberto (Novela).

En aquella ciudad (Novela).

Restrepo Jaramillo, José Lưus (Medellín 1893-1926)

Simbolo (Novela), en El correo liberal (Medellín).

Citada por Ospina, 414.

Restrero Mejía, Martín (Medellín 1861- )

Caminos inciertos.

"Novela histórica." Cat. Libr. Colombiana, 1945.

Restrepo de Norris, Agripina (Manizales 1907- )

Nelly.

Novela corta premiada con diploma de primera clase y medalla de oro en la Exposición de Bogotá en 1930. Citada por Ospina, 451.

RiBot, ANGEL (Bucaramanga)

En prensa: Albas de mayo (Novela).

RINCÓN ROZAS, SAÚL

Ana Josefa (Novela real colombiana de costumbres boyacenses). Tunja, Edit. Revolucionaria, 1935, 209. Pról. E1 autor. Foto. LC.

\section{Ríos Ocampo, Gonzalo}

Más allá de la sombra (Novela). Manizales, Edit. Atalaya, 1943, 327. Pról. Roberto Restrepo. Pref. El autor. BN.

Anuncia: Don silencio. "Novela cuasi-vernácula dedicada a la exaltación de las cosas de la tierra."

Rivas, Medardo (Bogotá 1825-1901)

Tradiciones de Tocaima, en Revista de Colombia (Bogotá); -, en Obras de Medardo Rivas (Bogotá, Fernando Pontón, 1883-1885, 2 v. BN I.C). V. $x, 147-160$. 
Dolores (Cuadro histórico), en Revisia de Colombia; --, en Obras de... (1883-1885), V. 1, 179-196.

Memorias de un ajusticiado, en Revista de Colombia; -, en Obras de... (1883-1885), V. I, 239-275.

Las dos hermanas, en Revista de Colombia; - en Obras de... (1883-1885), V. I, 425-468.

La novela en la historia, en Revista de Colombia; -, en Obras de .. . (1883-1885), V. I, 485-520.

Véase: Cortázar, "Apéndice," que cita además las siguientes obras: Las dos rosas, El destino, La vida en América, también publicadas en la Revista de Colombia. No sabemos a qué género responden.

Rivas Galtardo (Véase: Rivera y Garrido, Luciano)

Rivas Groot, José María (Bogotá 1863-1923)

Resurrección, en La opinión (Bogotá), 1901; - (Novela), 4 ed. Bogotá, Cándido Pontón, 1905, xvi-74. Pról. Andrés Vargas Muñoz, v1x. Carta: Armand de Nouvrac, XI-Xvi. BN LAC; - 5 ed. Madrid, Bibl. "Patria," s. f., 94. Ils. Luis Palao. Bibl. "Patria" de obras premiadas: 20. LAC; - en Cuentos (por José María y Evaristo Rivas Groot.) Bogotá, Minerva, 1936, 192. Pról. SSO: 15, 19-103; -, Barcelona, Herederos de Juan Gili, 1912, xxxvi-123. Pról. A. Vargas Muñoz. Ils. José Passos. Col. Elzevir ilustrada: 26. LAC Y.

Prólogo de la primera edición fechado en Bogotá, diciembre de 1902. ". . . la obra que, publicada incompleta y fragmentariamente en La opinión, el año pasado, fué acogida con entusiasmo..."

Dice Nouvrac en su carta fechada en Plombières, el 15 de agosto de 1905: ". . . se dedica al estudio de los sentimientos nobles, al análisis del alma de sus personajes ... Su propósito es $l_{a}$ moral, pero una moral suave, presentada con tan atractivo aspecto, en un estilo tan flúido, que al autor se le escucha y se le comprende aunque todos no participen en sus propias ideas ... escribe con el espíritu de un francés de nuestra época ... en los centros literarios (de Bogotá) se creyó en un principio que esa novela no era producto nativo de América, sino traducida de un autor francés a la lengua castellana." 
". . no es nuestra: refleja otro medio y caracteres; fué fruto de la crisis moral de Francia, que atrajo al catolicismo a Bourget y a Brunetière, y la cual crisis Rivas Groot debió sentir muy de cerca ... Es de un preciosismo florentino y de una delicadeza y de una suavidad encantadoras." Pról. (1912).

Trad. Fleur exotique. Véase: A. Vargas Muñoz, "Prólogo" (1912); Flor exótica. París, (Garnier ?), s. f. Véase: Cortázar, 100-103.

El triunfo de la vida. Madrid, Bibl. "Patria," 1916.

Novela premiada por la Bibl. "Patria" de Madrid.

Holocausto (Novela).

"Cuando falleció, iba a publicar otra, Holocausto, que no concluyó." Ortega, $\$ 70$.

Véase: Marroquín, Lorenzo, página 53 de éste, nota bajo Pax.

RIVERA, José Eustasio (Neiva 1889-1928)

La vorágine. Bogotá, L. Tamayo y Cía., s. f. [1924], 340. Foto. Y; -. 9 ed. New York, Edit. Andes, 1929, 368. Vocabulario, 345-347. Conceptos, 349-368. D LC; - 7 ed. Bogotá, Camacho Roldán, 1931, 384. Vocabulario, 353-356. Conceptos, 357-384. LC; -, Bogotá, Minerva, s. f., 327. Ils. Vocabulario, 313-314. Algunos conceptos, 315-327; - 1 ed. Buenos Aires, Espasa-Calpe, 1938, 266. Vocabulario, 263-266. Col. Austral: 35; ibid., 2 ed. 1939. D LC; - 1 ed. Buenos Aires, Losada, 1942; - 2 ed. 1944; - 3 ed. 1946, 254. Vocabulario: 251-254. NC; - Buenos Aires, Edit. Pleamar, 1944, 263. Ils. Julio Vanzo. Vocabulario, 261-263. LC NC; -, Montevideo, Imp. La anunciadora, s. f. 249; -, Buenos Aires, Tor, s. f. 235. Vocabulario. Bibl. Las Grandes Obras: 17. NC.

Trad. Der strudel. Leipzig, Hans Müller Verlag, 1934, 340. Trad. y pról. G. H. Neuendorff. Ils.; The vortex. New York, Putnam's, 1935, 320. Trad. Earle K. James; Pucbina. Moscú, 1935. Trad. Kelin; A vora gem. Rio de Janeiro, Edit. Leitura, s. f. [¿ 1945 ?]. Trad. José César Borba.

Véase: Carlos Wyld Ospina, en El repertorio americano, xuI, 1926, 181-183.

Rivera y Garrido, Luciano (seud. Rivas Gallardo) (Buga 1846-1899)

Un sentenciado a muerte, en El bien príblico (Bogotá). 
Citada por Cortázar, "Apéndice." "Novela de costumbres." Ospina, 479.

El sargento Pedro (Novela corta), en Ensayos literarios (Bogotá, 1871).

La novia del desertor (Novela corta), en Ensayos literarios.

La venganza de una mujer (Novela corta), en Ensayos litterarios.

Véase: Cortázar, "Apéndice," que llama novelas cortas a los tres últimos títulos.

Véase también: Ortega, 333-338.

RODRÍGUEZ (?)

Interrogantes sobre el destino. 186 páginas. BN.

Novela. Ejemplar mutilado. Falta la página titular.

Rodríguez Moya, Francisco (Santa Rosa de Osos 1884-

El nazareno.

Citada por Cortázar, "Apéndice."

Rojas S., Octavio LC.

Provinciana (Novela). Bogotá, Minerva, 1940, 408. Pról. El autor.

\author{
"En un rincón de los Andes \\ tuvo lugar un idilio: \\ las cuitas de los amantes \\ se cuentan en este libro."-Epigrafe.
}

Rosa, Amira de la

Marsolaire. Barranquilla, Talleres Gráficos Rasch, 1941, 49. BPB.

"... una novela corta que recoge en su paisaje y en su ambiente, sobre una anécdota recia y pasional, la tragedia del pueblo de Puerto Colombia, abandonado... desde que Barranquilla inauguró su Terminal Marítima." 
Rosal, Berta (seud.)

Unico amor, en La novela semanal, 1, 7, 1 de marzo, 1923, 70-77. BN.

Rosales de la Rosa, B.

Marta (Relato histórico en cien páginas de la vida de una heroina ignorada). New York, "Las novedades," 1913, 101: "Un prólogo en clos cartas": El autor y señora N. N. Foto. LC.

En prep. En el año 3000 (Novela).

Rozo, Jesús Silvestre (Guatavitá 1835-1895)

El último rey de los muiscas (Novela histórica). Bogotá, Echeverría bnos., 1864, 112. LAC.

e. . . notas alusivas a la historia, mitología y costumbres de los chibchas... reminiscencias de la entrada de los españoles al país, y noticias de las frecuentes guerras que tenían los naturales entre sí, y de la trágica muerte del denodado Tisquesusa, último vástago real de la raza indigena." OM, Hist., 239.

Las travesuras de un tunante (Historia que parece novela ... o cuadros de costumbres nacionales). Bogotá, "La América," 1873, 356. L.AC.

"Dividida en cincuenta y cuatro capítulos... La novela de costumbres es el termómetro que mide mejor los grados de civilización del pueblo, que el autor de ella ha tenido a bien retratar." El autor.

“... novela epigramática y jocosa ... de agradable sabor local... atinadas observaciones y críticas sobre nucstros defectos sociales, más o menos finas y oportunas." OM, Hist., 239.

Saldaña (Véase: Silvestre, Luis Segundo de)

Salgado, Alberto

Bajo la lente de Macrosofos. Bogotá, Cromos, s. f. [1946], 237. BN.

Samper, José María (seud. Juan de la Mina) (Honda 1828-1888).

Los claveles de Julia (Escenas de la vida peruana. Novela original), en Ia opinión (Bogotá), 1864; -, Bogotá, Zalamea hnos, 1881, vII-292. LAC. 
"Publicada en 1864, en el boletín del periódico político La opinión (Bogotá), con el título de Una taza de claveles." LA.

Escenas de la vida neogranadina, en El tiempo (Bogotá), 1864.

Citada por Cortázar, "Apéndice."

Viajes y aventuras de dos cigarros, en El mosaico (Bogotá), III, 1865 , 294 et passim.

Citada por Cortázar, "Apéndice."

Martin Flores (Novela). Bogotá, Imp. de Gaitán, 1866, 200. LAC Y.

Véase: Cortázar, 46-51.

Juan de la Mina. Bogotá, F. Mantilla, 1870.

Clemencia, en El deber (Bogotá).

Citada por Cortázar, "Apéndice."

Coriolano, cn El deber (Bogotá).

Citada por Cortázar, "Apéndice."

Un drama intimo (Novela original). Bogotá, F. Mantilla, s. $f$. [i 1870 ? ], 308, BN.

Florencio Conde (Escenas de la vida colombiana. Novela original). Bogotá, Echeverría hnos., 1875, 210.

- El poeta soldado (Escenas de la vida colombiana. Novela original). Bogotá, Zalamea hnos., 1881, 327. Carta: El autor. LAC LC Y.

Véase: Crítica anónima, repertorio colombiano, vr, 384-388.

Lucas Vargas. Escenas de la vida colombiana, en El domingo (Bogotă), 19 de marzo a septiembre de 1899 ; - (Novela inédita), Bogotá, Luis M. Holguín, 1899, 159. LAC.

La última de sus novelas, fechada en Anapoima, el 28 de diciembre de 1887 .

Samper Ortega, Daniel (seud. El Compadre Tigre) (Bogotá 18961943) 
Entre la niebla (Novela), en La novela semanal, $\mathrm{I}, 2,1$ de febrero, 1923, 11-20. BN Y; -, Bogotá, Minerva, 1926, 156.

La Marquesa de Alfandoque, en En el cerezal (véase abajo), 117-150.

Publicada por primera vez en 1923 , dato que no se pudo verificar.

En el cerezal (Acuarelas literarias de la sabana de Bogotá). Bogotá, Cromos, 1924, xII-122. Pról. Tomás Rueda Vargas. BN LC; -2 ed. Bogotá, Ed. Colombia, 1926, 150. Pról. Tomás Rueda Vargas (de la 1 ed.).

Contiene: En el cerezal, 13-114, y La Marquesa de Alfandoque, 117-150.

La obsesión. Bogotá, Cromos, s. f. [1926], 135. BN LC; - 2 ed. Bogotá, Minerva, 1936, 154. SSO: 18. BN LC T Y; - 3 ed. 1936.

"...tragedia sociológica... nombre nacido del enigma embrollante que en la imaginación le mantenía a uno de sus héroes la palabra honor ... Narra en trama novelesca y melancólica ... las peripecias... de las infelices mujeres atadas por un adverso sino a la coyunda medrosa de los caprichos despóticos del patrón que tiraniza sin piedad." Eduardo Martínez Villegas, Cromos, xxiv, 565, 9 de julio, 1927.

Vida de Bochica (Novela), 1928.

"... es una novela de pocas páginas, de mérito inferior a las anteriores." Ortega, 790.

Zoraya (Una vida de amor y santidad). Bogotá, Sociedad editora de obras nacionales, 1931; -2 ed. Bogotá, Minerva, 1931, 303. BN LC; - 3 ed. Barcelona, Araluce, 1935, 311. NC.

Véase: Carlos Gaxcía-Prada, Books abroad, vi, 3, July, 1932, 309; W/ade, 478.

Sánchez Gómez, Gregorio (Chocó 1895-1942)

La tierra desnuda. Bogotá, Juan Casís, 1920, 196. BN LAC Y.

Novela de costumbres.

La piedad del mar, en La novela semanal, 1, 18, 24 de mayo, 1923, 183-192. BN Y. 
La derrota (Novela de estudiantes, 1917). Panamá, "La moderna," 1925, iII-291. Pról. L. E. Nieto Caballero. BN.

"Es un noble evocador. Bogotá, la ciudad de sus estudios, se retrata en sus novelas con sus vicios y sus placeres... en Bogotá los estudiantes pueden encontrar la cumbre o el abismo. Es fácil en tentaciones y fácil para la caída. $Y$ aunque no es frecuente, no es tampoco raro el caso que Sánchez Gómez estudia en La derrota." Pról.

Rosario Benavides (Novela laureada por la Academia Colombiana). Cali, Edit. Relator, 1927.

"Novela de sociedad y vida moderna." OM, Hist., 249.

La virgen pobre (Novela de la vida obrera). Cali, Palau, Velázquez \& Cía., 1929, 289. BN.

La casa de los del Pino (Novela). Cali, Palau, Velázquez \& Cía, 1929, 319. BN.

"Novela psicológica, de índole reconstructiva." OM, Hist., 249.

El gavilán (Novela). Cali, Edit. América, 1933, 359. BN LC.

"... una pintura viva del labriego colombiano y una descripción de la vida campesina, en que se pinta la lucha entre el latifundista y el labriego." OM, Hist., 249.

Casada... y sin marido (Novela). Cali, Edit. América, 1934, 217. BSM.

Historia de un adulterio nacido de la incomprensión y la falta de cultivar los imperativos naturales.

Vida de un muerto (Relato novelesco, de fantasía y humorismo). Manizales, Arturo Zapata, 1936, 196. LC.

"Gregorio Sánchez Gómez es, positivamente, uno de los buenos humoristas con que cuenta América ... he aquí que ... crea ... un fantasma que vive, a pesar de estar muerto, o mejor, semi-muerto, y acciona en otros planos superiores a los nuestros, presentando por foro escenarios constituídos ex-profeso por el novelista." Ricardo Freyre, argentino, citado por AF, 84. 
El Burgo de Don Sebastián (Novela). Cali, Edit. América, 1938, 279. BN LC.

Anuncia como publicadas las siguientes novelas cortas (1933):

El monstruo.

La flor del tabaco.

El maniático.

El espiritu de don Celso.

La envidia de los dioses.

El no la mató, fué su pasado.

La fábrica (Novela de combate).

La piedad del mar.

Para publicarse (1933): El inútil pecado (Novela de sociedad, psicológica).

La amazona de Cañas (Novela romance del campo).

En prep. (1933): Doña Juana Tenorio (Novela satírica).

Sánchez Lafaurie, Juanita (seud. Marzia de Lusignan) (Bastidas)

Viento de otoño (Novela nacional). Bogotá, Cromos, 1941, 360. Pról. Félix Restrepo, S. J. y Antonio Gómez Restrepo. Foto. BPB LC.

". . estudia en su novela dos tipos femeninos estrechamente vinculados desde la infancia... pero muy distintos en su aspecto físico y más aún en su carácter . . . una historia dolorosa ..." Pról.

Santamaría, Eustasio

La confidencia del cura de mi pueblo, en El tiempo (Bogotá).

"José de la Cruz Rodriguez, en El tiempo.

Ambas citadas por Cortázar, "Apéndice."

Santamaría S., Francisco

Cesarea. Medellín, Imp. Editorial, s. f., 175. LAC. 
Scarpetta, Adriano (Cali 1839-1881)

Julia. Palmira, Teodoro Materón, 1871.

Eva (Novela caucana). Buga, Imp. del autor, 1873.

Serna V., Josí María

Un drama en Bogotá (Novela de costumbres). 1 ed. Girardot, Imp. Girardot, 1925, 129. Carta: El autor. Pról. G. Quevedo Z, BN.

SirRano, Nepomuceno

Paulina o los dos plebeyos, en El pestalozziano (Socorro).

Citada por Cortázar, "Apéndice."

SERVET, JUAN

La señorita Emma (Novela de costumbres colombianas).

Véase: L-GP, 68.

Servien, Juan (Véase: Nieto, Ricardo)

Sicambro (Véase: Silvestre, Luis Segundo de)

Sierra, Aquires

¡Viva la vida! (Memorias de un cuarentón). Medellín, Imp. del Departamento, 1934, 273. LC.

Silva, José Asunción (Bogotá 1865-1896)

De sobremesa. 1 ed. Bogotá, Cromos, 1925, 235; - 2 ed. Bogotá, Cromos, s. f. [̇ 1928 ?], 235. BN NC Y.

Silvestre, Luis Segundo de (seud. González Cortina; H. P. de P. H.; Hernán Pérez del Pulgar; Saldaña; Sicambro) (Bogotá 1838-1887)

Tránsito. Bogotá, Silvestre y Cía., 1886, 211. LAC Y; - (Novelita de costumbres americanas). Boston, Heath, 1932, IX-263. Edit. Frank W. Roberts. Ils. LC; -, Bogotá, Minerva, 1936, 170. Pról. Samper Ortega. SSO: 14. BN T Y. 
Véase: Cortázar, 14-17; OM, Hist., 238; José María Samper El repertorio colombiano, xII, 389-395.

Sonderéguer, Penro (Bolívar 1884- )

Cóndor (Novela). San José, C. R., 1904. BN.

Faltan casa editora y paginación.

Las fuerzas bumanas (Novela). Buenos Aires, Tor, 1918.

Cátedra de seducción (Novela extranjera). 2 ed., en El cuento (Bogotá), r, 4, 9 de junio, 1923, 49-64; -, Buenos Aires, 1924.

De mayor éxito editorial.

Todo el amor (Novela). Buenos Aires, Tor, 1921.

Quibdó (Novela). Buenos Aires, Maucci hnos., 1927, 259. LC.

El prodigio de Kipdó [sic], anunciada en prensa por Tor en 1926.

Las siguientes se citan en Los fragmentarios (1926) como novelas de Sonderéguer publicadas por Tor:

Gentes de medio pelo.

Las fronteras del espiritu.

El paraíso del diablo.

El miedo de amar (Novelas).

Lo que las mujeres no saben (Novelas).

Dicbosas en el mal (Novelas).

Periodista, dramaturgo, novelista, el autor vivió largos años en la Argentina. Luis Enrique Osorio le llama "el gran escritor colombiano." Soto Borda, Clímaco (seud. Casimiro de la Barra) (Bogotá 1870-1919)

Diana cazadora (Novela escrita en la guerra de 1900). Bogotá, Imp. Artística Comercial, 1915, 195. BN LAC Y; -, Bogotá, Edit. ABC, 1942, XII-180. Pról. B. R. BPCC, Novela: 5. BN LC.

"... trozos de costumbres regionales hermosamente tomadas de la realidad." OM, Hist., 195. 
"Novela humana como pocas, en la que describe las tribulaciones de un joven inexperto a quien Diana, ventera cazadora de hombres, arranca dinero y alegría hasta verlo morir en hospital de caridad, víctima de dolencia vergonzosa." BP, 83.

Stella, Luz (Véase: Cárdenas Roa, María)

SuÁrez, ARturo (Rosalba 1887- )

Montañera. Bogotá, Tip. Colón, 1916, 199. LAC Y; - 2 ed. Bogotá, Minerva, 1928, 224. BN D LC; — 4 ed. Bogotá. Edit. Kelly, 1945, 175.

"Obra que obtuvo el primer premio en los Juegos Florales verificados en Manizales el 29 de octubre de 1916." Dice el Fallo: "... digna de las maestras plumas de los padres de la novela antioqueña, Carrasquilia, Velázquez y Rendón."

El alma del pasado (Novela bogotana). Bogotá, Eustacio Ramos; 1921, 256. LAC Y'; - 3 ed. Bogotá, Edit. Santafé, 1936, 412. LC; 5 ed. Bogotá, Libr. Colombiana, 1940, 415 p. BN D; - 6 ed. Bogotá, Edit. ABC, s. f., 254. BN; - 8 ed. Bogotá, Minerva, 1945, 325.

Rosalba (Historia de un amor grande y verdadero). 2 ed. Bogotá, Cromos, 1924, 280. Pról. Max Grillo, 5-7; El autor, 8-9. BN; - 4 ed. Bogotá, Edit. Santafé, 1928, vuI-380. Pról. Max Grillo. LC; - $6 \mathrm{ed}$. Manizales, Arturo Zapata, 1938, vmi-388. Pról. Max Grillo. LC NC.

Ha habido 10 ediciones agotadas de Rosalba. "En Montañera... revélase el novelista caldense observador minucioso del alma del pueblo. Influído... por un autor español de exhuberante (sic) decir, muéstrase abundoso en el diálogo y pródigo en la facilidad descriptiva. En Rosalba ha moderado el novelista su querencia por el muelle balanceo de las tierras del trópico ....Es Rosalba una doncella campesina menos ideal que... María pero quizá de un relieve más húmano ... tiene por marco... los campos aledaños a Manizales..." Pról.

Asi somos las mujeres (Novela). Bogotá, Edit. Santafé, 1928, 457. BN LC.

"Recorriendo ... los encontrados parajes de la Cordillera Central, vecinos a Ibagué ... recogí de labios campesinos esta historia palpitante con sabor vernáculo y olor sencillo a montañeras flores..." Dedicatoria: El autor. 
El divino pecado (Novela). Bogotá, Minerva, 1934, 271. LC.

Sebastián de las Gracias (El gran cuento antioqueño narrado por ....). Bogotá, Edit. Santafé, 1942, 204. LC.

Adorada enemiga (Novela). Bogotá, Edit. ABC, 1943; 198. Preludio: Tagore. BN; -3 ed. Bogotá, Edit. Kelly, 1945.

Tablanca, Luis (Véase: Pardo Farelo, Enrique)

'T'ello Mejía, Salvador

Motilonia, o Andanzas de un antioqueño. Girardot, Edit. Girardot; 1934, 173. LC.

Las andanzas picarescas del protagonista Juan González, y sus comentarios mordaces sobre la vida contemporánea.

Tobar S., JoAquín

Una bistoria de once años. Bogotá, E. Torres Amaya, 1873, 24.

Tomás Calderón, Mauricio (Salamina 1891- )

60 minutos. Manizales, Arturo Zapata, 1933, 187. BN.

Toro, Bernardo (Nariño 1898- )

Minas, mulas y mujeres (Novela). 1 ed. Medellín, Tip. Industrial, 1943, 128. BSM; - 2 ed. 1943, 134. Pról. Manuel Mosquera Garcés. BN LC.

"Sin pujos de sociólogo, sin impulsos de cómitre, sin efímeras pedanterías de letrado suficiente, va mostrando desde el principio ... lo que es Antioquia ... Verdadero escrutinio de vocabulario popular (y aún del plebeyo) podría hacer el erudito apasionado por estas manifestaciones del folklore, ya que abundan ... los giros peculiares, los modismos de casa, campo y calle, las expresiones de vívido realismo..." Pról.

Torres Torrente, Bernardino (Facatativá 1813-1886)

Sombras i misterios o Los embozados (Obra histórica). Bogotá, Francisco Torres Amaya, 1859, 217. Pról. Reseña histórica. Introito, 3-15. Foto. BN LAC; -2 ed. 1874. 
"Contiene los sucesos más notables de ... Bogotá... desde 1849 hasta $1851 \ldots$ hechos que más tarde figurarán en la historia, aunque me hayan servido para la confección de csta novela; he preferido esta forma i estilo con el fin de amenizar la narración... Viven aún muchos personajes que figuran en esta obra, pero no haré uso de sus propios nombres, sino cuando sean absolutamente indispensables." Pról.

El ángel del bosque. Recreaciones morales-Libro para la familia (Novela original). Bogotá, Imp. de Gaitán, 1876, vi-263. Pról. El autor. BPC.

"... la escena de esta novela en ... el bello valle del Cauca ... el protagonista ... siempre dejando escapar de sus labios la palabra ... Amor... una obra de recreaciones morales, de lecciones instructivas para todos." Pról.

Véase: Ladrón, 561.

Las dos enlutadas, en El vergel colombiano (Bogotá?).

LA: "Novela corta publicada en El vergel colombiano.".

Ujueta Sánchez, JoaquíN

Lucrecia o la rosa de Damasco. Bogotá, Nicolás Pontón, 1875, 61.

Uribe Holguín, Alberto

La leyenda de los duendes. Una peregrinación al lazareto. Bogotá, Edit. Marconi, 1925, 83.

Uribe Piedrahita, César (Medellín ¿1885 o 1897?- )

Toá (Narraciones de caucherías). Manizales, Arturo Zapata, 1933, Iv-1 80. Pról. Antonio García. Glosario. Ils. Alberto Arango Uribe. BN LC; - Buenos Aires, Espasa-Calpe Argentina, 1942, 152. Pról. Antonio García, 11-14. Glosario, 147-152. Col. Austral: 314. BN LC NC.

"César Uribe es, sin duda alguna, más novelista que Rivera. Capta con mayor justeza y mayor intensidad. Rivera describe fantásticos volúmenes policrominados, César Uribe paisajes sombríos de colores crudos; Rivera se complace perdiéndose en un bosque suntuoso de parábolas, César Uribe en esconder su estilete amargo y dejar que la espuma del río haga arabescos sobre figuras monstruosas y sencillas... Novela his- 
tórica, científica, social y política ... en la cual se hacen valerosas acusaciones y sorprendentes revelaciones a propósito de la vida de los caucheros del Putumayo y Caquetá. Los personajes figuran en la obra con sus nombres propios y las narraciones están documentadas personalmente por el autor." Pról.

Véase: Wade, 478.

Mancha de aceile. Bogotá, Renacimiento, 1935, 138. Glosario. Ils. Gonzalo Ariza. BN D LC NC.

"... novela de las petroleras venezolanas, con una tesis anti-imperialista insinuada en el proceso de un proceso amatorio. Uribe Piedrahita es un hombre en ascuas ardido de inquietudes: médico, arqueólogo, dibujante $\mathrm{y}$ finalmente novelista de grandes posibilidades." AF, 87.

Véase también, Latcham, 6-7.

Para publicarse: Caribe (Novela).

Valencia, Octavio (Popayán 1890- ）

Marbella (Novela de costumbres colombianas). Bogotá, Minerva, 1920, 68. Pról. Carlos Arturo Torres (fechada en Bogotá, 1910). Vocabulario. LAC.

Pertenece a la familia de Maria La acción pasa en La Cauca y en Bogotá.

Valmar, Jame (Véase: Rendón, Francisco de Paula)

Vallejo, Arejandro (Manizales 1902- )

Entre Dios y el diablo (Novela). Bogotá, Minerva, 1931, 135. BN LC.

Véase: AF, 85-86; Latcham, 25-27, con referencia a ésta y la que sigue.

La casa de Berta Ramírez (Novela). Bogotá, Minerva, 1936, 206. LC NC.

"Nuestra eterna tarea es improvisar. Nuestra vida, esta vida colombiana es inconexa ... Flotamos entre una balumba de comienzos; de cabos desprendidos... Alentamos en el reinado de lo transitorio."

En prep. Los políticos (Novela política). 
VALLEJo E., José

Fantasías. Jérico, Imp. Municipal, 1911, 67. BN.

Tipo de novela de viaje imaginario. Dice al final: "Fin de la primera parte. Un viaje imaginario, por mapa, por el Chocó."

Vargas VILA, José María (Bogotá 1860-1933)

Aura, o las violetas. Bogotá, 1892, 131. Pról. El autor. BN (falta la página titular); - Nueva ed. París-México, Vda. de Ch. Bouret, 1898, virl-295. Contiene Aura, 3-90, Emma, (Novela), 93-130, y Lo irreparable (Narración sobre un hecho histórico), 133-295. Bibl. de los novelistas; ibid., 1906. LAC; ibid., 1920. Y; ibid., 1930. LC; 一, Barcelona, Ramón Sopena, s. f. [ ¿192 ?]. Y. Obras completas (1920-1922, 48 v.) : 6 .

"...esa trilogía que empieza con Aura o las violetas, sigue con Emma y termina en Lo irreparable." Andrade Coello, ob. cit., 13. Véase también: Ladrón, 577.

Flor del fango. 1 ed. 1898 (?); -, París-México, Vda. de Ch. Bouret, 1921, 256. Bibl. de los novelistas. Y; - Obras completas (Sopena) : 14, xII-296; - Buenos Aires, sin edit., 1931, 159. Ch.

"En Flor de [sic] fango, obra de vivas imágenes, se entrevé un fin laudable: el triunfo de la virtud ... Se ven las injusticias de la tierra, las maquinaciones del mal, pero, sobre todas estas mezquindades, flota una epopeya distinguida, un alma de mujer de hierro, una virginidad salvada." Andrade Coello, ob. cit., 14.

Véase también: César Zumeta, El cojo ilustrado, vir, 137-138. Fechada en Nueva York, 1898.

Ibis. 1899; -, Roma, 1900; -, 1902. Sin.ningún dato bibliográfico. Ch; - París, Libr. Americana, 1920, xx-248. Bibl. de los novelistas. $\mathrm{Y} ;$ - Obras completas (Sopena): 2.

Trad. Ibis. São Paulo, Edit. Prometeu, 1944, 244. Trad. Galvão de Queiroz.

Véase: Andrade Coello, ob. cit., 61-64; Ladrón, 577; F. Tosta García, en El cojo ilustrado (Caracas), rx, 185-186.

Alba roja. Barcelona, s. f. [1901], xx-279; -, París, Libr. Americana, 1903, 245. LAC; - Obras completas (Sopena): 4. 
"Alba roja ... alude a los horrores del partido vencedor sobre el vencido, al odio de aldea, al fanatismo de las ciudades pequeñas contra los que alguna innovación traen o hablan de libertad... El protagonista es Luciano Miral (aunque pudiera haber dos protagonistas, porque son dos cuentos que muy bien irían cada cual por su camino) tal vez la encarnación del periodista liberal autor del relato..." Andrade Coello, ob. cit., $44-45$.

Las rosas de la tarde. París-México, Vda. de Ch. Bouret, 1901, 286; ibid., 1906; - Obras completas (Sopena): 13; - s. 1. (Argentina), sin edit., 1935, 160. Ch.

Véase: Andrade Coello, ob. cit., 64-66.

Los parias [¿1903?]. París, Lib. americana, 1914, 279. Il; ibid., 2 ed. 1926. LC; - Obras completas (Sopena): 16, Xrv-282.

Andrade Coello (ob. cit., 54, nota) afirma que Vargas Vila "empezó el libro Los Parias en Florencia, en Septiembre de 1902 y lo concluyó en París en Enero de 1903." El mismo comentarista da de la novela una crítica bastante larga; véanse sus páginas 52 ss.

La simiente. París-México, Vda. de Ch. Bouret, 1905, 245; ibid., 1906. LAC; - Obras completas (Sopena): 1, xxI-262.

Véase: Andrade Coello, ob. cit., 87-93; Jesús Semprum, en El cojo ilustrado, $\mathrm{xv}, 186-187$.

El alma de los lirios. París, Vda. de Ch. Bouret, 1914, viri-510; $V u e l o$ de cisnes (E1 lirio blanco-El lirio negro). Barcelona, Ramón Sopena, 1917; Delia (Lirio blanco), Obras completas (Sopena): 20, xrx-218; Germania (Lirio negro), Obras completas (Sopena): 23, xvin-236.

Delia y Germania anulan las ediciones de El alma de los lirios y Vuelo de cisnes.

Véase Andrade Coello, ob. cit., 93-147.

Trad. Lirio vermelbo. Rio, Vecchi, 1947.

La demencia de Job (Novela). Madrid, A. Rubiños, s. f. [1916], 2.23. Conceptos, 167-223. Ch LC; - Obras completas (Sopena): 15, $\mathrm{xxxt}-205$.

Rosa mistica (Mes nouvelles). Barcelona, Maucei, 1917, 252. Ch. 
Los discípulos de Emaïs. (Novela de la vida intelectual). Barcelona, Maucci, 1917, 217. LC; - Obras completas (Sopena): 7, xx-213.

Eleonora (Novela de vida artística). Barcelona, Maucci, s. f. [1917], 319. Ch Y; - (Lirio rojo). Obras completas (Sopena): 22. Y.

El buerto del silencio. Barcelona, Maucci, s. f. [1917], 236. LC; Obras completas (Sopena): $43, \mathrm{xV}-235$.

Véase: Wade, $475-476$.

El cisne blanco (Novela psicológica). Barcelona, Maucci, 1917, 223. Ch Y.

Los estetas de Teópolis (Novela). Madrid, A. Rubiños, 1918, vm216; - Obras completas (Sopena) : 8, 1922, xv-232. Pról. El autor. LC.

Sobre las viñas muertas, Obras completas (Sopena): 3, xxIv-212.

María Magdalena (Novela lírica), Obras completas (Sopena): 5, 263 ; - Habana, Edit. Cárdenas, s. f., 94. Epílogo, 91-94. Ch.

El camino del triunfo, Obras completas (Sopena) : 10, xvIr-230; Habana, Edit. Cárdenas, s. f., 96. Ch.

Véase: Andrade Coello, ob. cit., 66-67.

La conquista de Bizancio, Obras completas (Sopena): 11, xvi-252.

Continuación de El camino del triunfo.

"... es producto de un hombre enfermo y aburrido que, por el prisma de sus dolencias y sus nervios, ve las cosas: todas le resultan de negro color..." Andrade Coello, ob. cit., 78 et passim.

El minotauro, Obras completas (Sopena): 12, xxxr-220.

Salomé, Obras completas (Sopena): 24, vi-251; -, Habana, Edit. Cárdenas, s. f., 93. Ch.

El final de un sueño, Obras completas (Sopena): 27,$285 ;-, \mathrm{Ha}-$ bana, Edit. Cárdenas, s. f., 95. Ch.

Continuación de El minotauro.

La ubre de la loba, Obras completas (Sopena): 28, 269 .

Continuación de El final de un sueño. 
Cacborro de león (Novela de almas rústicas), Obras completas (Sopena): 30,252 .

El sendero de las almas (Novelas cortas), Obras completas (Sopena): 31 , XIII-262.

Gestos de vida, Obras completas (Sopena): 53, Xrv-300. Y.

"Novelas cortas."

Mi smejores cuentos (Novelas breves). Madrid, Prensa Popular, s. f. [i 1922 ?], 191. X.

Contiene: La gran victoria; La sembradora del mal; Otoño sentimental.

La novena sinfonia (Novela). Madrid, Bibl. Nueva, s. f. [e 1928 ?], 421. Pról. El autor, 7-17. Ch LC.

Trad. Die neunte sympbonie (Roman). Berlin, Eden-Verlag, 1933, 320. Trad. G. H. Neuendorff. LC.

Italo Fontana (Novela). Barcelona, B. Bauzá, s. f., 272.

El maestro (Novela). La Habana, Montalvo y Cárdenas, 1935, 154. Ch LC T.

Véase: AF, 83-84.

Obras póstumas de Vargas Vila, para publicarse:

En los jardines de Lesbo. (Novela).

El tigre (Novela).

El oasis (Novela).

VARNEY, LEON (seud.)

El sentido de una vida. Bogotá, Imp. Eléctrica, 1906.

Véase: Ladrón, $579-580$.

Velázquez, SAmuel (Santa Bárbara 1865-1941)

Al pie del Ruiz. Medellín, C. A. Molina, 1898, 559. Y. 
"Libro formado por una serie de cuadros de costumbres, donde se estudia la vida de tres familias antioqueñas: distinguida la una, pobres y humildes las otras, pero siempre con la honradez y decencia que el señor Velázquez da a la gente del pueblo." Cortázar, 78-83.

Véase también: M. Lorenzana, El repertorio colombiano, XvIII, 1898, $461-465$.

Hija. Manizales, Tip. Caldas, 1904, 60. BSM.

Madre, en El muevo tiempo literario (Bogotá), 13-14, 1908; Bogotá, Cromos, 1923, 63. Y; -, Bogotá, Minerva, 1936, 158. SSO: 19. Pról. Samper Ortega.

Además de Madre, 13-73, la edición de 1936 contiene obras de Jesús del Corral, Pedro Uribe Gómez y Alfonso Castro.

"... en un concurso de novelas colombianas, obtuvo, entre cincuenta y ocho opositores, el primer premio, con Madre, la mejor de sus obras, vertida hoy al francés y al polaco." Ortega, 360.

"Madre obtuvo el primer premio en un concurso (de la Miscelánea) calificado por Fidel Cano, entre otros; ... más que un relato es un cuadro tan vivo, tan lleno de calor, que al terminar la lectura podríamos afirmar que hemos viajado con los arrieros y cortejado, nosotros también, a la sin par Inés; tales son la exactitud y propiedad de esa joya vernácula." Pról.

Para un estudio muy favorable de la novela, véase: "Samuel Velázquez," por L(atorre) en El montañés (Medellín), 1 , 1, septiembre de 1897, 1-12; véase también: Marco Tulio Salazar, Repertorio americano, Iv, $167-168$.

Véase: Cortázar, 76-78.

El abismo (Novela corta). Bogotá, 1910.

Velázquez Ortiz, Nicanor

Rio y pampa. Ibagué, 1944.

"Novela descriptiva del paisaje y de la vida tolimenses." Véase: Cat. Lbr. Colombiana, 1945 . 
Vélez, Bernardo (Medellín 1885- )

La muerte en los labios, en La novela scmanal, 1, 15, 3 de mayo, $1923,155-164, \mathrm{BN} \mathrm{Y}$.

El caso de Susanita, en El cuento semanal, 1, 7, 30 de junio, 1923, 95-107.

Senda roja (Novela corta).

Publicada por Gabriel Cano. Citada por Ospina, 929.

"Publicó La ley del embudo, Rosa mística, La recaída, novelas cortas, cuentos y crónicas publicadas especialmente en Sábado, El espectador, El correo liberal, Lecturas dominicales, La novela semanal y Lectura brere." Ospina, 929.

Vélez Barrientos, Lucrecio (seud. Gaspar Chaverra) (Bello 18501925)

Rara avis (Novela). Medellín, Libr. Restrepo, 1911, 191. LAC Y.

De costumbres antioqueñas e intrigas familiares.

Segundas mupcias.

Citada por Ospina, 928.

VÉLEZ SÁENZ, JULLo

Vidas de Cain. Manizales, Arturo Zapata, 1947.

"Y ésta es la indispensable ficción literaria de mi libro. Cinco personajes - los ojos con que Caín mira- hablarán sucesivamente de su vida y de lo que ella les ha enseñado para lograr una posible felicidad humana..."

Vergara y Vergara, Eradio (Bogotá 1821-1888)

El mudo, secretos de Bogotá. Bogotá, J. A. Cualla, 1848, 701.

‘. . la primera novela escrita en la altiplanicie... remontóse a los años de 1827 y 1828 para desenvolver a nuestra vista un imaginario relato, al que trató de dar las proporciones $y$ aspectos de una gran novela, como las en boga por entonces . . . Cual pintura de las costumbres de la época..., la obra del señor Vergara es, en suma, muy apreciable y digna de encomio:" OM, Hist., 226-227. 
Vergara y Vergara, José María (Bogotá 1831-1872)

Olivos y aceitunos, todos son unos (Novela de costumbres). Bogotá, F. Mantilla, 1868, vI-226. "Advertencia": J. M. Quijano Otero, I-vr. Pról. 3-7.

Véase: Cortázar, 12-14.

Vernaza, José Ignacio (Cartago 1887- )

En prensa: Hogares de antaño (Novela).

Yarilpa (Véase: Caicedo Rojas, José)

Yaromín, Pierre (Véase: Jaramillo González Guillermo)

Zalamea Borda, Eduardo (Bogotá 1907- )

4 años a bordo de mi mismo (Diario de los sentidos. Novela). Bogotá, Edit. Santafé, 1934, 478. Bibl. de los penúltimos: 3-4. LC; 一, Buenos Aires, Max Nieto, 1948.

"... está reputada como uno de los más acertados esfuerzos... por crear la novela nacional."

Véase: AF, 87-88; Latcham, 13-16.

En prep. Sexo. Tríptico novelesco que integran: Al lado de mi cuerpo-Gentes en menguante-Limite de espumas.

'La noche'-diario de la mañana (Novela).

Zapata Olivella, Manuel

Tierra mojada. Bogotá, 1947. Pról. Ciro Alegría.

Primera novela del autor, de tema proletario.

Zorlo Expedito (Véase: Botero Saldarriaga, Roberto)

Zola, Gustavo

Sangre roja (Novela). Medellín, Edit. Cóndor, 1939, x-168. Pról. El autor. $\mathrm{BN}$. 
Zuleta Angel, Eduardo (Remedios 1862-1937)

Tierra virgen. Medellín, Carlos A. Molina, 1897, 403. BN LAC Y. "... novela regional... en primer lugar entre las que de Antioquia han salido..." Lorenzo Marroquín, Revista nacional (Bogotá), 1, 3, julio de 1897, 212-223.

Véase: Cortázar, 83-86; Max 'Theim, El repertorio colombiano, xvi, 1897, 300-305; Wade, 476.

Zuluaga Uribe, Daniel

Yo la vi... (Novela corta), en Defensio vitae... (Novelas) (Cartagena, 1925, 208. Pról. El autor. BN), 11-123.

Concha... (La pobrecita!) (Novela corta), en Defensio vitae..., 129-180.

En la mitad del alma... (Novela corta), en Defensio vitae.... $185-208$. 
